\title{
The qualitative characteristics of financial information, and managers' accounting decisions: evidence from IFRS policy changes
}

\author{
Christopher W. Nobes ${ }^{\mathrm{a}}$ and Christian Stadler \\ ${ }^{a}$ School of Management, Royal Holloway, University of London \\ Egham, Surrey, TW20 OEX, UK \\ and \\ Discipline of Accounting, University of Sydney \\ chris.nobes@rhul.ac.uk \\ ${ }^{b}$ Department of Accounting and Finance, Lancaster University Management School \\ Lancaster, Lancashire, LAI 4YX, UK \\ c.stadler@lancaster.ac.uk
}

March 19, 2015

The authors are grateful for comments from Mary Barth, Vivien Beattie, Jürgen Ernstberger, Richard Macve, Brian Singleton-Green, Steve Young, Stephen Zeff, Na Zhao, Ann Tarca (the guest editor), two referees of this journal and workshop participants at the 2014 British Accounting and Finance Association Annual Conference, the 2014 European Accounting Association Annual Congress and the Inaugural IASB Research Forum in 2014, especially Niclas Hellman (the Academic Commentator) and Mary Tokar (the IASB Commentator). They are grateful for historical documents from Martin Persson and research assistance from Shiyun Song and Guojing Tang. Financial support was provided by the Department of Accounting and Finance at Lancaster University Management School. 


\title{
The qualitative characteristics of financial information, and managers' accounting decisions: evidence from IFRS policy changes
}

Editors' Note: One of the authors of this paper is one of the editors of this Special Issue. Therefore this paper was handled by the other editors, using the normal double-blind reviewing system.

\begin{abstract}
:
This is the first empirical study that uses publicly available data to provide direct evidence about the role of the qualitative characteristics (QCs) of financial information in managements' accounting decisions. Based on 40,895 hand-collected IFRS policy choices on 16 topics made by 514 large firms of 10 jurisdictions in the period 2005-2011, we identify 204 reasons for policy changes. The majority of these refer to QCs from the conceptual framework of the standard-setter, in particular to relevance, faithful representation, comparability and understandability. Firms also frequently refer to transparency, which is not directly mentioned in the framework. Furthermore, we analyse the circumstances under which firms explain their policy changes in terms of improved quality. We hypothesise and find that QCs are more often referred to if the change relates to measurement (i.e. to a more important accounting policy decision). We also find that references to QCs are positively associated both with firm size and with a measure of a jurisdiction's transparency. This complements previous research by providing evidence that managers are, at the least, alert to QCs.
\end{abstract}

\section{JEL Classifications: M41}

Keywords: qualitative characteristics; IFRS; relevance; faithful representation; comparability, understandability; transparency 


\section{Introduction}

If financial information is to be useful, it must be relevant and faithfully represent what it purports to represent. The usefulness of financial information is enhanced if it is comparable, verifiable, timely and understandable.

(IASB 2010, paragraph QC4)

The qualitative characteristics (QCs) of financial information, as set out in the Conceptual Framework (hereafter, Framework) of the International Accounting Standard Board (IASB), are fundamental for standard-setting and are intended to be used by firms when they make certain accounting decisions, in particular policy choices and policy changes (IASB 2010, 'Purpose and status'). The Framework is under review, including a willingness to re-examine QCs (IASB 2013, paragraph 9.3 and Question 22, p. 193). This means that research findings are of unusual topicality for policy makers.

As will be explained, the QCs section of the Framework has existed in two versions: the original (IASC 1989) and the revised (IASB 2010). These contain such concepts as relevance, reliability, faithful representation, comparability, verifiability, timeliness and understandability. With the possible exception of timeliness, these are abstract. Indirect evidence about these concepts has been obtained using empirical proxies, e.g. assessments of the value relevance of financial information based on regressions of price on accounting items such as earnings (Barth et al. 2001, Hail 2013); of the determinants of asymmetric timeliness of earnings, based on regressions of earnings on returns (Basu 1997, LaFond and Watts 2008); of the benefits of comparability, as measured by the similarity of a firm's earnings-return relationship to other firms (De Franco et al. 2011); and of the understandability of accounting narratives based on readability and comprehension tests (Smith and Taffler 1992, Jones and Smith 2014). However, there is no direct empirical evidence on the role of the QCs in managements' accounting decisions. 
We therefore ask which QCs managers refer to when explaining their accounting decisions, and when they refer to QCs. Managers usually do not provide reasons for their accounting decisions, at least not publicly. However, one source of such information relates to changes in accounting policy. International Financial Reporting Standards (IFRS) allow choice on many policy topics; much more so than do US Generally Accepted Accounting Principles (US GAAP), for example. ${ }^{1}$ If managers change a choice, they should provide an explanation (IAS 8.29 (b)). Particular QCs are often stated as reasons for a policy change, which allows us empirically to analyse them.

We use the following terminology: a firm makes a policy choice by selecting an option on a given topic; it makes a policy change by selecting a different option from that of the previous year. An example of an IFRS policy topic is the presentation of operating flows in the cash flow statement; the available IFRS policy options are the direct and indirect methods. An explanation of a policy change is a statement in the annual report which provides one or more reasons for the change. Examples of reasons are improved understandability and an allegedly beneficial effect on the financial statements (e.g. reducing volatility of earnings). Strictly speaking, according to IAS 8, a reference to reliability or relevance is not a 'reason' for a policy change because IAS 8 asks for the reason why the change provides 'reliable and more relevant information'. We take account of this distinction but our main analyses treat reliability and relevance as reasons because we are interested in any reference to QCs. We acknowledge that we are studying stated reasons which may differ from the real reasons, and we return to that point in our conclusions.

The source of our data is 40,895 hand-collected IFRS policy choices on 16 topics, as found in the 2005-2011 financial statements of 514 firms from 10 jurisdictions (hereafter,

1 Of the 16 topics in Table 1, on which there was overt choice in IFRS in 2011, there was no overt choice in US GAAP for topics 5, 8, 9, 10,11, 13 and 16. We are not aware of other major topics on which there was choice in US GAAP but not in IFRS. 
'countries'). ${ }^{2}$ From these policy choices, we identify 434 policy changes. Of these, 147 are explained with one or more reason, and this provides our evidence about the reasons given when firms make policy changes. We discuss later whether this implies non-compliance.

As some of the explanations contain more than one reason, there are 204 reasons in all. More than half of these refer to QCs from the Framework, in particular to relevance, faithful representation, comparability and understandability. Firms also frequently refer to transparency (Barth and Schipper 2008), which is not directly mentioned in either version of the Framework. We then analyse the circumstances under which firms make policy changes for which they claim improved quality. We hypothesise and find that QCs are more often stated if the change relates to measurement. We also find that references to QCs are positively associated both with firm size and with a measure of a country's transparency. However, despite findings in the literature that firms from common law countries exhibit higher accounting quality than firms from code law countries (e.g. Ball et al. 2000, Ball 2006), our results do not indicate that firms from common law countries claim more frequently that their changes improve quality.

This paper contributes to the literature in several ways. First, and most importantly, it is the first to provide direct empirical evidence on the role and importance of the QCs of financial information in managements' accounting decisions. Instead of using empirical proxies for QCs based on the perspective of researchers, the data used are the publicly disclosed reasons given for managers' decisions. The paper therefore provides evidence on how QCs are used in a real context. It complements prior research on QCs such as relevance (Barth et al. 2001) and comparability (De Franco et al. 2011), by showing that managers refer to these QCs. Additionally, the scope of our empirical work is wider than that in prior literature because our methodology allows us to analyse a large set of QCs instead of just one

2 One of these jurisdictions is Hong Kong. Despite this, for simplicity, we refer to 'countries' hereafter. 
or a limited number. Second, it extends the literature on international comparisons of accounting quality (e.g. Ball et al. 2000) by suggesting that a measure of a country's transparency is positively associated with references to QCs. Third, the paper extends the research on (IFRS) accounting policy choice (Kvaal and Nobes 2010, 2012) by being the first content analysis of reasons given for policy changes.

The paper proceeds as follows. Section 2 provides background, reviews the literature, states the research questions and develops a hypothesis. Section 3 describes the sample and data. Section 4 contains the empirical analysis. Section 5 concludes.

\section{Background, literature review, research questions and hypothesis}

\section{Qualitative characteristics of financial information}

For millennia, ${ }^{3}$ accounting was carried out without a perceived need for a conceptual framework that set out relevant objectives, definitions and concepts. This continued even when financial reporting became compulsory for some entities (e.g. in the UK's Companies Act 1844). ${ }^{4}$ In several continental European countries, academic theorists constructed frameworks of ideas in the early twentieth century (Zambon 1996), but these were not directly contained in any regulations. In the European Union (EU), the Fourth Directive (which was published in first draft in 1971 and adopted in 1978) also did not contain objectives or definitions. It did ${ }^{5}$ contain six 'principles', which are therefore found in EU laws: going concern, consistency over time, prudence, accruals, separate valuation, and correspondence of the opening balance sheet with the former closing balance sheet (Article 31). These were a compromise between German and UK ideas (Nobes 1983). ${ }^{6}$

3 Macve (2014a) is an example of papers which discuss accounting over that span.

4 In the case of the 1844 Act, the compulsion was limited to sending an annual balance sheet to the shareholders, and this requirement was repealed in 1856, not to return until the twentieth century.

5 In 2013, the Directive was revised. The six principles were retained, but more were added.

6 Nobes (1983) records that the first four were to be found in the UK's Statement of Standard Accounting Practice No. 2 (Disclosure of Accounting Policies) of 1971; and that going concern and accruals had not been in the 1971 draft, before the UK joined the 'Common Market' in 1973. 
In the US, several academics had by then constructed frameworks of ideas (e.g. Paton 1922, Canning 1929, MacNeal 1939); and it was there that an extensive conceptual framework was first explicitly set forth by an accountancy body. In 1959, the American Institute of Certified Public Accountants (AICPA) set up the Accounting Principles Board (APB) and also an Accounting Research Division. The latter wrote ${ }^{7}$ Accounting Research Study No. 1 (The Basic Postulates of Accounting) in 1961 and Accounting Research Study No. 3 (A Tentative Set of Broad Accounting Principles for Business Enterprises) in 1962. These documents contained definitions (e.g. of asset and liability) and a series of 'postulates' which mixed concepts (e.g. the entity and going concern) with desirable qualities of accounting information (in particular, objectivity and consistency, as postulates 2 and 3 on pp. 41-3). However, Studies 1 and 3 were rejected by the APB because some of their content was too different from existing practice, and the APB eventually produced its own, mostly descriptive, set of principles as Basic Concepts and Accounting Principles Underlying Financial Statements of Business Enterprises (APB Statement No. 4) in 1970. Chapter 4 of that deals with objectives, leading to a discussion of QCs which gives primacy to relevance ahead of verifiability and neutrality (Schattke 1972, p. 238).

Meanwhile, the American Accounting Association, the organisation of academic accountants in the US, had published A Statement of Basic Accounting Theory (ASOBAT) in 1966 which was 'revolutionary’ (Sterling 1967, p. 95). It took a deductive approach rather than drawing on existing practice. ASOBAT was never accepted by the APB. Its conclusions appear strikingly modern. It put decision-usefulness at the top of its objectives for accounting (p. 4), and set out (p. 7) four 'basic standards ${ }^{\prime 8}$ for accounting information: relevance, verifiability, freedom from bias, and quantifiability. After that, there were five guides for

7 The documents were published by the AICPA, but the Director of Accounting Research (Maurice Moonitz, an academic) notes that publication was 'under his authority'. The first was written by Moonitz; the second by Robert Sprouse (another academic) and re-drafted by Moonitz.

8 The word 'standards' in its current meaning appears to have originated in the UK with the foundation of the Accounting Standards Steering Committee in 1969 (Rutherford 2007, p. 37). 
communication: appropriateness to use, disclosure of significant relationships, inclusion of environmental information, uniformity of practice within and among entities, and consistency of practices through time. These desiderata would now be called 'qualitative characteristics'. Many of them are to be seen in the later frameworks of the IASB and the Financial Accounting Standards Board (FASB).

In 1971, the AICPA set up two committees ('Wheat' and 'Trueblood') which led, respectively, to the founding of the FASB in 1973 and to its acceptance of the need to define the objectives of financial reporting on which to base standard-setting. The Trueblood Report (AICPA 1973, ch. 10) begins the process of applying its objectives (principally decisionusefulness), by suggesting QCs, summarised by Zeff (2013, p. 283) as 'Information must be relevant and material, substance should rule over form, and the information must be reliable, free from bias, must promote comparability, and should be consistent and understandable'.

The FASB produced as series of documents on concepts, starting with one on objectives. That of most relevance to this paper is Concepts Statement No. 2 (of 1980) on Qualitative Characteristics of Accounting Information. This puts relevance and reliability at the top of a hierarchy of qualities. The broad ideas behind these qualities had been established in the earlier documents, such as ASOBAT, but their exact definitions and weighting were new and have been attributed to David Solomons, who had been a member of the Wheat Committee and was the draughtsman of Concepts Statement No. 2 (Gore 1992, pp. 111-2, Zeff 1999, p. 109).

Concepts Statement No. 2 is the direct ancestor of the Framework of the International Accounting Standards Committee (IASC 1989). This was adopted ${ }^{9}$ by the IASB, who eventually amended the sections on objectives and QCs in 2010, and then published further proposals for amendment, though not of the QCs (IASB 2013). However, as will be

9 Stephen Zeff (in a letter of 7 August 2014) notes that there is no evidence of this in the minutes of the Board's meetings, but the Framework was always included in the IASB's annual books of documents. 
explained, the most relevant document for this paper is the Framework of 1989. That version of the Framework set out four principal QCs: understandability, relevance, reliability and comparability. Other subsidiary qualities (including neutrality and prudence) were described, as shown in Figure 1. The terms are explained in Appendix 1. ASOBAT's word 'verifiability' did not originally appear in the Framework, although it was in the FASB's Concepts Statement No. 2 (as a constituent of reliability). It was introduced into the IASB's revised Framework in 2010, as a partial replacement for reliability (IASB 2010, paragraph QC26), as noted below. The FASB's objectives and concepts were revised jointly with the IASB (FASB 2010). ${ }^{10}$

< insert Figure 1 about here >

The principal purpose of the Framework is to assist the Board when setting accounting standards (paragraph 1). The Framework is also intended to be of general use to preparers (and auditors) when interpreting and applying standards. Although it is not a standard, ${ }^{11}$ preparers of IFRS financial statements are directed towards the Framework and its QCs under three circumstances: (i) when departing from the requirements of IFRS in 'extremely rare circumstances' (the 'override'), according to IAS 1.19 (see Nobes 2009), (ii) when developing an accounting policy to cover a transaction not specifically dealt with by IFRS, according to IAS 8.7-12, and (iii) when changing an accounting policy, according to IAS 8.14-15.

This paper is concerned with the third of these issues (policy change), which far more commonly involves disclosures than do the other two issues. ${ }^{12}$ In the context of policy change, IFRS gives prominence to two of the four QCs, because it only allows a voluntary change in policy (as opposed to one required by a change to IFRS) if it 'results in the financial statements providing reliable and more relevant information' (IAS 8.14 (b)). Not only are the

10 Concepts Statement No. 8 of 2010 replaced Concepts Statements No.s 1 and 2.

11 That is, it is not part of IFRS. It can be inconsistent with parts of IFRS. In the EU, it is not part of the endorsed content of IFRS.

12 By definition, the first type is extremely rare. For the second type, IAS 8 does not require any disclosures. 
two QCs promoted here above the others, but relevance outranks reliability: the new information must be more relevant, subject to maintaining a threshold level of reliability. IAS 8 imposes another type of constraint on voluntary policy change, in that it requires ${ }^{13}$ retrospective application (IAS 8.22) and a number of disclosures, including an explanation of how the new information is reliable and more relevant (IAS 8.29). The disclosures of the change and the reasons for it are only required if the change 'has an effect' on past, present or future financial statements. As always under IFRS, this means a material effect (IAS 1.29 and IAS 8.8). The implication is that any change that is disclosed should also be explained. ${ }^{14}$

Our empirical study of policy changes relates to 2005 to 2011 . In that period, various versions of IAS 1 and IAS 8 were in force, but they all referred ${ }^{15}$ to the Framework as issued in 1989. Nevertheless, given that the changes to QCs introduced in 2010 were also previously aired in a discussion paper and an exposure draft, some firms might have taken account of them in our period. The revised document of 2010 has two 'fundamental' QCs: relevance (including materiality) and faithful representation. Four ‘enhancing' QCs are comparability, verifiability, timeliness and understandability. Reliability is not specifically mentioned, although the IASB has explained that its meaning is mainly now included in 'faithful representation' (IASB 2010, paragraph BC3.24). This was contentious (Whittington 2008, EFRAG 2013a). Furthermore, prudence was deleted in 2010, on the grounds that it is inconsistent with neutrality. Prudence had always been a controversial QC (e.g. Zeff 2013, p. 287), and its deletion was also controversial amongst standard-setters (EFRAG 2013b),

13 IAS 8.23 allows an exception when that is 'impracticable'.

14 Materiality is an aspect of relevance (IASB 2010, QC11), so there should not be disclosures of the existence of immaterial changes. Therefore, the disclosure of a change implies that it is material and should therefore be explained. Despite this, in our data, there are nine cases of disclosed but unexplained changes which were said to have no material effect.

15 In the IASB's 'bound volume' of standards for 2011 onwards, footnotes have been added to IAS 1 and IAS 8 which mention that a revised 'Conceptual Framework' has been issued, but these footnotes have not been through 'due process' and are not in the EU-endorsed or the Australian versions of the standards (EU countries and Australia comprise six of the ten countries in our empirical analysis). 
academics (Whittington 2008) and some investors. ${ }^{16}$ The IASB has announced an intention to re-insert prudence as part of the current revision (IASB 2014).

\section{Prior research on qualitative characteristics}

Some prior studies investigate a specific QC: relevance (Koonce et al. 2011), reliability (see the review of Maines and Wahlen 2006), timeliness (e.g. Ball and Brown 1968), comparability (e.g. De Franco et al. 2011), understandability (e.g. Jones and Smith 2014) and transparency (e.g. Barth et al. 2013). The empirical literature uses empirical proxies in order to draw inferences about the respective QC, often based on a relationship between earnings and returns. Experimental studies (e.g. Hunton et al. 2006) allow analysis of a specific QC more directly, but they also involve interference by the researchers, i.e. designing an experiment that generates data about the QC.

Other papers analyse two QCs together. One such pairing is relevance and reliability, which were the two primary QCs of the FASB and the IASB until 2010. Most frequent are value relevance studies, which generally jointly test relevance and reliability (Barth et al. 2001, p. 81). Using experiments, Kadous et al. (2012) suggest, in the context of fair value measurement, that users do not view relevance and reliability as independent constructs. Analysing standard-setters, Power (2010) suggests that the concept of reliability was stretched by the FASB and IASB in order to accommodate more use of fair value, which was seen as more relevant (decision-useful). Investigating this development empirically, Allen and Ramanna (2013) find that FASB members with backgrounds in financial services tend to propose standards which decrease reliability and increase relevance. Another pair of QCs is timeliness and conservatism. Timeliness is measured as the sensitivity of a firm's earnings to returns, and, following Basu (1997), conservatism is the higher sensitivity to negative returns.

16 For example, the UK's Local Authority Pension Fund Forum and other investors commissioned a legal opinion (from G. Bompas QC, dated 8 April 2013) which cast doubt on the legality of IFRS for various reasons, including the removal of prudence. 
More timely and more (conditionally) conservative earnings are generally regarded as being of higher quality (e.g. Ball et al. 2000, Ball 2006, Dechow et al. 2010).

There are very few papers which investigate more than two QCs. Joyce et al. (1982) examine US standard-setting in the context of the conceptual framework (SFAC 2) via an experiment with 26 former board members of the APB or the FASB. They investigate a set of eleven QCs and their results suggest that the set is comprehensive but not parsimonious, and that only two QCs (verifiability and cost) are operational. The only study which uses publicly available data from the preparers of financial statements (i.e. managers) in order to (indirectly) analyse a large set of QCs is van Beest et al. (2009). They split the main QCs into 21 items, drawing somewhat on the questions proposed by Jonas and Blanchet (2000) for assessing the quality of financial reporting. Van Beest et al. (2009) apply their approach by scoring the items for 120 firms, some using IFRS and some US GAAP. They find no significant difference in quality between the GAAPs but a relationship with other factors, e.g. size and industry. Given that QCs are abstract and difficult to measure via empirical proxies or in an experiment, conducting a survey or interviews can be used to generate data about QCs.

Dichev et al. (2013) ask chief financial officers (CFOs) the following open-ended question: 'What does the concept of earnings quality mean?' (Table 3, p. 12). Among the most frequent categories of responses is that it 'accurately reflects economic reality, accurately reflects the results of operations' which is consistent with faithful representation; the responses also include 'transparency/clarity' and 'conservative'.

\section{Prior research on IFRS policy choice and the economic determinants of accounting choice}

Table 1 shows 16 IFRS policy topics on which firms had a choice in the period 2005 to $2011 .{ }^{17}$ Kvaal and Nobes (2010) examine the choices made in 2005 by 232 large listed firms

17 These are the topics included by Kvaal and Nobes (2010). It would be possible to identify a few more. For example, André et al. (2012) appear to have 25. However, several of these are not really policy choices, e.g. depreciation method (which an entity is supposed to identify rather than choose) and whether or not segment 
from five countries on those topics. They found that firms tended to continue with their preIFRS policies where that was possible under IFRS. As a result, national profiles of IFRS practice were clearly apparent. Nobes and Stadler (2013) analyse 14 of the 16 topics for large listed firms from twelve countries in 2011 and provide evidence of sectoral differences in IFRS policy choice. Cairns et al. (2011) examine policy choice on the topics for which fair value is an allowed option, finding limited use of it, except for investment property. The results of Christensen and Nikolaev (2013) suggest that this use of fair value for the measurement of investment property is particularly associated with firms whose primary activity is real estate.

\section{< insert Table 1 about here >}

Kvaal and Nobes (2012) examine the policy changes, from 2005 to 2008, made by the firms which they had studied earlier. They expect and find few changes for two reasons: (i) the continuation of various national pressures that caused the original policy choice, and (ii) the constraints in IAS 8, referred to above. However, Kvaal and Nobes (2012) find some evidence that French and Spanish firms moved away from previous national practices, thereby increasing international comparability. Haller and Wehrfritz (2013) present findings for Germany and the UK relating to policy choices from 2005 to 2009, and also find little change.

We analyse QCs and our data are IFRS policy changes, which are a particular type of accounting choice. Holthausen and Leftwich (1983), Watts and Zimmerman (1986) and Fields et al. (2001) provide comprehensive reviews of the literature on accounting choice. The economic factors most often associated with accounting choices include political costs (e.g.

information is disclosed. As a footnote to Table 1 explains, two options were removed for 2009 onwards. Additionally, there was no choice in Australia for topics 7 and 16 for accounting periods beginning before 1 July 2007. It would be possible to argue that some of these topics are really matters of estimate rather than policy, e.g. topic 14 on inventory costing. However, the strong association of policy with country (Kvaal and Nobes 2010) suggests that choice is involved. 
Watts and Zimmerman 1978, Hagerman and Zmijewski 1979), debt covenants (e.g. Hunt

1985, Sweeney 1994) and compensation arrangements (e.g. Healy 1985, Bamber et al. 2010).

\section{Research questions and hypothesis}

No prior paper provides direct empirical evidence on the role and importance of the QCs of financial information in managements' accounting decisions. We therefore ask the following two research questions: which QCs do managers refer to when explaining their accounting decisions, and when do they refer to QCs? Our context for addressing these questions is IFRS accounting policy changes. We choose this context for two reasons: as noted earlier, policy change is the most common context for references to QCs, and there is much greater scope for policy choice (and, therefore, policy change) under IFRS than under US GAAP. In the highly unlikely case that we find no references to QCs, ${ }^{18}$ the simple answer to our research questions would be that managers do not refer to QCs when they change their accounting policies, regardless of the circumstances.

Our first research question (which QCs are referred to?) is exploratory. Regarding our second research question (when are QCs referred to?), we expect that managers and auditors feel more concerned that a policy change should be justified with reference to a QC if the change is perceived to be important. We propose that the more important changes are those that affect the size of accounting numbers rather than just their presentation. Therefore, our hypothesis is:

H1: Managers more frequently explain a policy change by referring to QCs when the change concerns a measurement choice rather than a presentation choice.

18 We will find references to QCs unless one of the following three conditions applies to all of the policy changes that we analyse: first, the policy change falls outside the scope of the requirement to provide an explanation for improved relevance; for example, early adoption of a new or amended standard (see IAS 8.20); or, second, the firm does not comply with the requirement to explain (IAS 8.29); or, third, the firm provides a reason but it is not a QC. 
In our empirical analysis, we also investigate whether firm size, leverage, profitability and country factors such as cultural differences are associated with references to QCs.

\section{Sample and data}

Table 2 provides details about our sample of firms and our data on IFRS policy changes. The sample comprises the largest ${ }^{19}$ firms from ten countries: Australia (AU), Switzerland $(\mathrm{CH})$, China (CN), Germany (DE), Spain (ES), France (FR), United Kingdom (GB), Hong Kong (HK), Italy (IT) and South Africa (ZA). These countries have large stock markets and firms using IFRS since 2005 or earlier. ${ }^{20}$ We exclude foreign firms and firms which never used IFRS as their (main) accounting principles in our sample period of 2005 to 2011 . We also exclude firms with less than two years of data because two years of data are necessary in order to identify policy changes. Based on this procedure, our sample comprises 514 firms.

\section{$<$ insert Table 2 about here >}

The remainder of Table 2 shows how we use data on IFRS policy choices in order to identify reasons for the policy changes based on managements' explanations. These data are from published annual reports, generally from the accounting policies section of the audited financial statements. First, we hand-collect 40,895 IFRS policy choices on the 16 topics shown in Table 1 for our sample firms for the period 2005 to 2011 (not tabulated). Our second task is to use this data to identify all the policy changes in the statements of 2006 to 2011 , whether or not the changes are specifically mentioned by the firms. As Table 2 reports, IFRS

19 That is, we use the constituents of the main stock market indices on 31 December 2005 or 31 December 2010 or both: S\&P/ASX-50 (Australia), SMI (Switzerland), Hang Seng China Enterprises Index (China), DAX-30 \& 10 largest (by market capitalization) constituents of MDAX-50 (Germany), IBEX-35 (Spain), CAC-40 (France), FTSE-100 (United Kingdom), Hang Seng (Hong Kong), (S\&P/MIB-40) FTSE/MIB-40 (Italy) and FTSE/JSE Top 40 (South Africa).

20 Although China has not fully adopted IFRS, the majority of the largest listed Chinese firms prepares IFRS financial statements, because they are listed on the Hong Kong Stock Exchange (HKEx), which required IFRS from 2005 to 2009. Consequently, Chinese firms with a listing in Hong Kong and Mainland China prepared two sets of financial statements (IFRS and Chinese GAAP). However, from 2010, HKEx accepts Chinese GAAP financial statements, and six firms in our sample have stopped preparing IFRS financial statements. 
policies are rarely changed: we found 434 changes; on average, only $1.2 \%$ of the policies used in the reports of 2006 to 2011 were changes from the previous period. There are some international differences: French firms changed $1.7 \%$ of their policies whereas UK and Italian firms only changed $1.0 \% .{ }^{21}$ Untabulated results show similar differences between industries according to the first digit of the Industry Classification Benchmark (ICB): utility firms changed $1.6 \%$ of their policies whereas consumer goods firms only changed $0.9 \%$. However, more than half of our firms (261 out of 514) made at least one change in our period. We tested whether these firms were economically atypical, but found no evidence of that. ${ }^{22}$

Our third task is to search for explanations of IFRS policy changes. About one quarter of the firms (122 out of 514) provide an explanation for at least one change. ${ }^{23}$ Considering all 434 policy changes, firms provide explanations for 147 of them $(34 \%) .{ }^{24}$ Some of these explanations contain more than one reason, leading to 204 reasons, which are our key data. ${ }^{25}$ The number of reasons reduces to 176 if we exclude reliability and relevance as being insufficient because IAS 8 requires reasons why the change provides reliable and more relevant information. However, most of the appearances of reliability and relevance are accompanied by an additional reason (see Section 4), so excluding them still means that $32 \%$ of changes are explained (not tabulated).

21 The proportion of IFRS policy changes to total choices differs significantly across the 10 countries (based on a $\chi^{2}$ test of independence: $\chi^{2}$ test statistic $=19.57$, p-value $=0.02$ ).

22 Our sample comprises 261 firms which made one or more policy change, and 253 firms which made no change. We do not find statistically significant differences in firm size, leverage and profitability between the two types of firms (policy changers and not), using two-sided $t$-tests and data from 2005 (or the first available year if a firm has not yet been listed in 2005); the means (p-values) for the variables SIZE, LEVERAGE and PROFITABILITY are 15.917 vs 16.015 (0.34), 0.001 vs $-0.008(0.60)$ and -0.004 vs -0.001 (0.60), respectively. See Appendix 3 for the definitions of the variables.

23 When we repeat the analysis described in the previous footnote for the two types of firms (explanation providers and not), we do not find statistically significant differences in firm size, leverage and profitability. The means (p-values) are 15.985 vs 15.960 (0.84), 0.002 vs -0.005 (0.71) and -0.006 vs $-0.001(0.50)$, respectively.

24 The proportion of IFRS policy changes which are explained does not differ significantly across the 10 countries (based on a $\chi^{2}$ test of independence: $\chi^{2}$ test statistic $=10.02$, p-value $=0.35$ ).

25 Both authors each did the entire scoring. 
We employ content analysis in order to find the reasons given for IFRS policy changes.

The following provides three examples of how we code the explanations of policy changes:

(1) 'The directors of the Company are of the view that the change in accounting method for interests in jointly controlled entities would provide more reliable, relevant and comparable information [...].' (Shenzhen Expressway, Annual Report 2007, p. 109)

(2) 'We believe this revised presentation will provide users of our financial statements with a better understanding of our business.' (Imperial Tobacco, Annual Report and Accounts 2007, p. 71)

(3) 'This change provides information that is clearer and more relevant.' (Unilever, Annual Report and Accounts 2011, p. 68)

The first example contains three reasons: reliability, relevance and comparability. The second example has one reason: better understanding, which we score as 'understandability'. ${ }^{26}$

Several explanations do not explicitly refer to particular QCs but can still be coded on an 'inferred' basis. For instance, the third example shows (in addition to 'relevance') what we label 'understandability (inferred)'; i.e., we infer from the reference to 'clearer' that one of the reasons for the change was to improve understandability. Appendix 2 provides details of our data collection and coding procedures.

As noted above, only $34 \%$ of our 434 policy changes are explained, leaving 287 changes unexplained. This is despite the fact that 427 (98\%) of the changes were audited by Big 4 auditors (auditor data are hand-collected). This appears to suggest considerable noncompliance with IAS 8's requirement to explain policy changes. However, explanations might not be required in some of these 287 cases because the changes have no material ${ }^{27}$ effect on the financial statements (IAS 8.29, first line). Nevertheless, the change is mentioned for 53 of the unexplained changes, which implies that those changes are material and should therefore be explained.

26 It could be argued that 'better understanding of our business' refers to faithful representation. However, neither 'faithful representation' nor any reference to better presentation of information is explicit in this explanation. Our coding is based on an objective approach as described in Appendix 2.

27 IAS 8.29 does not specifically include the word 'material' but IFRS requirements do not apply unless amounts are material (IAS 1.29 and IAS 8.8). 
Some of the information in Table 2 contrasts with the conclusions of prior literature. For example, Kvaal and Nobes (2012) find that French and Spanish firms made more policy changes between 2005 and 2008 than UK firms did. They suggest that this was because French and Spanish firms were less familiar with IFRS and therefore made less settled choices on transition in 2005. However, while our data (relating to a longer period; 2005 to 2011) agree about French and Spanish firms, we find that Italian firms do not make more changes than UK firms even though the same logic should have applied to them as to France and Spain. Additionally, Swiss firms make a relatively high number of changes after 2005 even though most of them had been using IFRS from well before 2005 .

Table 3 shows the number of policy changes per topic and country in the 2006 to 2011 period. The amount of change varies substantially by topic: four topics $(4,5,10$ and 11$)$ have fewer than ten changes whereas some topics display a relatively large number, e.g. topics 6 , 12 and 15 each have more than 50 changes. Additionally, the changes often have a common direction, e.g. for topic 15 , the change is usually towards treating actuarial gains and losses as other comprehensive income (OCI). There are no changes of the measurement basis of investment property (topic 11) from 'fair value' to 'cost', which is in line with the statement in IAS 40.31 that it is 'highly unlikely' that such a change would 'result in a more relevant presentation'. However, while firms are 'encouraged to report cash flows from operating activities using the direct method' by IAS 7.19, more firms changed away from the direct method than towards it (6 vs 4). This is an example of managers' making a choice against the standard setter's explicit view on useful information.

\section{< insert Table 3 about here >}

The numbers in brackets in the last column of Table 3 show the number of changes that have explanations. A possible reason for a topic to have a low proportion of explained changes is that managers do not consider such changes to have a material effect on the 
financial statements, e.g. changes on topic 2 (operating profit shown or not). Additionally, we observe few explanations for changes in inventory costing (topic 14), which might be because some preparers consider these to be changes of estimate (i.e. changes in inventory usage) rather than of policy, such that IAS 8.14 (b) does not apply. ${ }^{28}$ The measurement topic with the smallest proportion of explanations for policy change is designation of financial instruments at fair value (topic 12). Topic 12 is unusual in that an apparent change in policy (to or from some designation) might be caused by acquiring or disposing of a particular type of financial instrument, which we later refer to as 'item is new' and 'previous choice is no longer applicable'. This would probably not require explanation, and we identify 15 such changes. Unfortunately, there might be further cases because annual reports often do not provide enough detail to assess this. When we test our hypothesis, we show that our results are robust to excluding topic 12 .

\section{Empirical analysis}

\section{Reasons for IFRS policy changes}

Table 4 reports the frequencies of reasons given for IFRS policy changes, by category. Our content analysis identifies four broad categories of the explanations for policy changes: (1) 'Qualitative characteristics - Framework' includes the QCs referred to in the Framework of the IASC/B (reliability, relevance, faithful representation, comparability, verifiability, timeliness, understandability, prudence/conservatism and accruals/matching). (2) 'Qualitative characteristics - other' relates to transparency, which is not specifically mentioned in the Framework. (3) 'Economic' includes firm event (e.g. a merger), effect on financial statements (e.g. reducing volatility of earnings) and economic/managerial environment. (4) 'Other' includes changes due to another policy change, early adoption of a standard, an anticipated

28 This matter was considered by the IFRS Interpretations Committee in September 2014 (Staff paper, Agenda ref 12D). 
change to a standard and the requirements of a local regulator (the latter mainly applies to requirements of the Spanish regulator of financial institutions). The table shows where our scores are 'inferred' (i.e. not explicitly stated) for some QCs (faithful representation, understandability and transparency). Appendix 2 provides examples for each category.

$$
\text { < insert Table } 4 \text { about here > }
$$

As explained earlier, we identify 204 reasons for policy changes (included in the explanations for 147 changes). This allows us to answer our first research question, i.e. which QCs managers refer to in their accounting decisions. Managers frequently mention relevance (25 times), faithful representation (24 times), comparability (45 times) and understandability (11 times).

Given that the 2010 Framework considers the concept of reliability to be mainly subsumed within faithful representation, there might be an argument for combining the two in our data. However, this would make little differences because of the paucity of references to reliability (only 3). By contrast, managers frequently refer to transparency (18 times), which is not directly mentioned in the Framework, although Dichev et al. (2013, Table 3) provide evidence that CFOs consider it to be a feature of earnings quality. This raises two questions: what is transparency capturing that is not captured in the Framework's QCs, and should the IASB insert a discussion of transparency in the Framework? We discuss possible policy implications in our conclusions (Section 5).

For our period, we are not able to discern any systematic change over time in the pattern of the above reasons for policy changes. Less frequent reasons for changes are reliability (3 times), verifiability (once), prudence/conservatism (once) and accruals/matching (once); and timeliness was not referred to at all. Given the controversy about the removal of prudence from the Framework in 2010, it is interesting to note how seldom managers refer to it. 
More than half of the 204 reasons (i.e. 111) refer to QCs found in the Framework of the IASB. ${ }^{29}$ After adding references to transparency, there are 129 references to QCs. The last part of Table 4 breaks down the category with the highest frequency: comparability. ${ }^{30}$ Many managers state that the policy change makes the firm's reporting more comparable to that of industry peers (16 times) or achieves comparability with local GAAP (14 times); the latter all relate to Chinese firms which changed towards the policy in their Chinese GAAP statements. ${ }^{31}$ Industry comparability seems to matter much more to managers than international comparability does.

In an attempt to shed some light on whether the reasons given by managers are trustworthy, we investigate the 16 references to industry comparability (hereafter, ' 16 cases'). We choose this reason because we believe that we can identify a reasonable benchmark for it, i.e. the choices of other firms in our sample which have the same first digit of the Industry Classification Benchmark (ICB) in the year of the change. For example, Woodside Petroleum changed from direct operating cash flows, which is the IASB's preferred option and the typical Australian choice (see e.g. Kvaal and Nobes 2010), to the indirect method in 2008. Consequently, the new choice made it comparable to $83 \%$ of world-wide industry peers in our sample compared to $17 \%$ under the previous choice. When we make this comparison for all 16 cases, we find clear evidence of increased industry comparability due to the changes: on average, the new choices are comparable to $56 \%$ of industry peers compared to $24 \%$ under the previous choices. $^{32}$

29 Of these 111, all but one reference is to QCs found in the 1989 version; the one exception is a reference to verifiability.

30 We do not attempt to distinguish between comparability and uniformity (see e.g. Macve 2014b).

31 We consider the 'comparability local GAAP' reason to be different from standards driven reasons. Of the 14 cases, 10 are about topic 16, and all changes were from proportionate consolidation of joint ventures to the equity method. However, in 2011 three Chinese firms still used proportionate consolidation, including Air China, which is a state-owned enterprise. We would not observe such varied practice if there were a local requirement.

32 The sum of $56 \%$ and $24 \%$ is less than $100 \%$ because some of our topics allow more than two options (see Table 1). 
As an alternative analysis, we investigate whether the new choice of a firm made it more comparable to industry peers than the previous choice, as was true for Woodside Petroleum. We find that 13 out of 16 cases result in more industry comparability. ${ }^{33}$ If we exclude the two cases where firms changed the presentation of the income statement to what we score as 'neither by function nor by format' (c), then 13 out of 14 cases result in more industry comparability.

The remaining reasons given for policy change are 31 references to 'economic' and 44 to 'other'. A firm event is the most frequent 'economic' reason (14 times) and early adoption of a standard the most frequent 'other' reason (24 times).

The second and third columns of Table 4 distinguish, by category, whether one reason or more than one reason is provided in an explanation of policy change. Of the 204 reasons, 106 are 'one reason only'. Of these, there are only seven instances of relevance and none of reliability, which is probably because IAS 8 requires an explanation in terms of reasons why the change provides reliable and more relevant information. In the 'other' category, usually only one reason is provided.

The last column of Table 4 reports the frequencies and proportions for measurement topics only, i.e. for changes relating to topics 10 to 16 . Overall, 115 reasons (56\%) relate to measurement topics. A test of proportions shows that measurement topics are overrepresented in the 'faithful representation' and 'effect on financial statements' categories, and under-represented in the 'economic/managerial environment', 'due to another policy change', 'early adoption of standard' and 'requirement of local regulator' categories (the results are statistically significant at the 5\% level using a two-sided test).

33 The results are similar when we use a narrower definition of industry peers: i.e. when we use other firms in our sample which have the same first two/three/four digits of the ICB code, the numbers are 58\% vs $22 \%(12$ out of 16 ), $57 \%$ vs $25 \%$ (12 out of 16 ) and $56 \%$ vs $23 \%$ (12 out of 16), respectively. 
Table 5 reports the results of univariate analyses of the reasons given for IFRS policy changes, based on two-sample tests of proportions. Considering all 204 reasons, QCs are significantly more frequently stated as reasons than are 'economic' and 'other' combined (63\% vs 37\%, respectively). This is still true if transparency is excluded because it is not directly mentioned in the Framework (60\% vs $40 \%$ ). This result is also robust to excluding reliability and relevance as being insufficient explanations (57\% vs $43 \%$ ). Considering only the 129 reasons which refer to QCs, comparability is significantly more frequently mentioned than relevance (35\% vs 19\%). Finally, there are significantly more references to QCs for a measurement change than for a presentation change (65\% vs 35\%). The last test provides initial support for our hypothesis concerning the greater importance of policy changes which affect measurement.

\section{$<$ insert Table 5 about here >}

\section{When do managers explain IFRS policy changes by referring to qualitative characteristics?}

In order to answer our second research question (i.e. when do managers explain policy changes by referring to QCs?) and to test the related hypothesis, we now perform regression analyses. The bottom of Table 2 describes the regression sample. We first consider all firmyear observations with one or more policy change, ${ }^{34}$ both those with and those without an explanation. We then exclude firm-year observations in which a firm mentions a change but provides no reason because the effect was said to be immaterial and those in which a firm does not provide an explanation because the item is new or the previous choice is no longer applicable (which mainly applies to topic 12). Our regression sample comprises 323 firm-year observations. $^{35}$

We estimate logistic regression models of the following general form:

34 The firm-year observation with the most changes is International Power in 2011 with six changes.

35 There are 257 firm-year observations with one policy change, 56 observations with two changes, eight observations with three changes, one observation with four changes and one observation with six changes. 


$$
\begin{aligned}
\mathrm{QC}_{\mathrm{it}}=\alpha & + \text { topic }_{\mathrm{it}} \beta+\text { country }_{\mathrm{it}} \gamma+\text { industry }_{\mathrm{it}} \delta+\theta \text { SIZE }_{\mathrm{it}}+\lambda \operatorname{LEVERAGE}_{\mathrm{i}, t-1} \\
& +\mu \text { PROFITABILITY }_{\mathrm{i}, \mathrm{t}-1}+\sigma \text { USLIST }_{\mathrm{it}}+\varepsilon_{\mathrm{it}}
\end{aligned}
$$

where QC is a dummy for a qualitative characteristic as a reason for a change; $i$ and $t$ denote firm and time, respectively; topic, country and industry denote vectors of variables; and $\varepsilon$ denotes the regression disturbance term. Since a firm can have one or more policy changes in a given year, the variable QC takes a value of ' 1 ' if there is a reference to a $\mathrm{QC}$ in at least one explanation of a change. In our default regression specification, the topic variables are dummies for the 16 IFRS policy topics, the country variables are dummies for the countries, and the industry variables are dummies for the industries according to the first digit of the Industry Classification Benchmark (ICB).

In the regression specification used to test our hypothesis, the topic variables are MEASUREMENT (a dummy for a change of a measurement choice) and NOT2OPTIONS (a dummy for a change which is not to or from using two options on a topic, e.g. first in, first out for some inventories and weighted average for others). The NOT2OPTIONS variable takes a value of ' 1 ' if there is a change which is neither to nor from using two options on a topic. In our data, using two options on a topic simultaneously can only apply for topics 6 and 14 (see Table 1). This variable is included because managers might not consider a change to or from using two options to be important enough to warrant an explanation. For firm-years with more than one policy change, MEASUREMENT (NOT2OPTIONS) takes a value of ' 1 ' if there is at least one change of a measurement choice (change which is not to or from using two options on a topic).

We also include variables for economic factors found to be associated with accounting choice, as discussed earlier. First, SIZE (the natural logarithm of market capitalization in US dollars) is a proxy for political costs; additionally, recent studies find that larger firms have higher accounting quality (see Dechow et al. 2010) and therefore might be more concerned 
about the quality of their financial information when making accounting choices and changes. Then, we include pre-change LEVERAGE (total liabilities divided by total assets) to proxy for debt covenants, and PROFITABILITY ${ }^{36}$ (return on assets) for compensation arrangements. Both variables are industry-mean ${ }^{37}$ adjusted, as described in Appendix 3, because leverage and profitability of most financial firms in our sample are not comparable to those of other firms. We also include USLIST (dummy for a US listing) because of the different regulatory environment of firms which have a US listing. Summary statistics of the variables are provided in Panel A of Table 6, and Appendix 3 provides more details on the definitions of the variables.

\section{< insert Table 6 about here >}

Panel B of Table 6 reports the regression results (marginal effects at means), which are based on standard errors clustered by firm because our sample includes firms which make policy changes in more than one year. ${ }^{38}$ The first regression shows that eight topic dummies are statistically significant at the 5\% level. That is, managers more frequently state QCs as a reason for a policy change if the change relates to TOPIC1 (income statement format), TOPIC5 (liquidity order of the balance sheet), TOPIC7 (direct or indirect cash flow), TOPIC10 (property measurement), TOPIC11 (investment property measurement), TOPIC15 (treatment of actuarial gains/losses), or TOPIC16 (treatment of joint ventures); and they less frequently refer to QCs if the change relates to TOPIC6 (OCI or statement of changes in equity). There is no reference group for the topic fixed effects because there are firm-year observations with more than one policy change and therefore more than one topic dummy

36 The variable PROFITABILITY $\mathrm{t}_{\mathrm{t}-1}$ has an extreme observation and is therefore winsorized at the $1^{\text {st }}$ and $99^{\text {th }}$ percentiles.

37 Our results are robust to using industry medians instead of means for the adjustment.

38 The sample includes 248 firms: 179 firms with one firm-year observation (i.e. year with at least one policy change), 63 firms with two observations and six firms with three observations. 
with a value of ' 1 '. The entire set of topic variables is statistically significant at the $1 \%$ level (untabulated, based on a Wald test). ${ }^{39}$

When we rank the significant topic variables in the first regression from high to low according to their marginal effect, we observe that four of the top five variables are for measurement topics. Topic 5 has the highest marginal effect and is a presentation topic, but a change for this topic only occurs six times in our sample. Furthermore, we observe a negative marginal effect for topic 6 , which is a presentation topic. Overall, this evidence is consistent with our hypothesis.

In the second regression, we replace ${ }^{40}$ the topic variables with MEASUREMENT (in order to test our hypothesis) and NOT2OPTIONS. This analysis shows that QCs are more often stated if the change relates to measurement (MEASUREMENT); the result is statistically significant at the 5\% level, which supports our hypothesis. Additionally, QCs are significantly more often stated if there is a change which is not to or from using two options (NOT2OPTIONS). The significance of the variable MEASUREMENT increases when we do not include NOT2OPTIONS (untabulated, marginal effect $=0.151, z$-statistic $=3.09 * * *$ ).

Regarding the country fixed effects, in the first regression, Spanish (ES), French (FR) and Hong Kong (HK) firms refer less frequently to QCs than do UK firms (the reference group), based on a $1 \%$ significance level. This suggests some country effect. A frequently used variable for classifying countries is the common/code legal dichotomy. It has been found that firms from common law countries exhibit higher accounting quality than firms from code law countries (e.g. Ball et al. 2000, Ball 2006), although the relevance of this legal dichotomy has been questioned (e.g. Lindahl and Schadéwitz 2013). When we replace the country dummies in our regression with COMMONLAW (dummy which takes a value of ' 1 ' for

39 It tests the null hypothesis that the coefficients of all variables of the respective set are equal to zero. Our Wald tests are based on the coefficient estimates and standard errors of the logistic regressions, not the marginal effects and corresponding standard errors.

40 All of our topic variables are either about measurement or presentation. 
common law and ' 0 ' for code law), it is not statistically significant (untabulated, marginal effect $=0.016, z$-statistic $=0.36$. Consequently, we do not find that firms from common law countries claim more frequently that their changes improve quality. ${ }^{41}$

Continuing to seek an explanation for the country effect, we estimate a third regression in which we replace the country dummies with a culturally-based variable, using the 'secrecy vs transparency' scores of Braun and Rodriguez (2008, Table 2) which operationalise Gray's (1988) framework and are based on Hofstede's (1980) data. Our variable, TRANSPARENCY, is the 'secrecy vs transparency' scores multiplied by -1 , so that a higher value implies more country-level transparency. Although the ultimate data source is old and much criticised (e.g. McSweeney 2002, Baskerville 2003), our regression shows that references to QCs are positively associated with TRANSPARENCY, which is statistically significant at the $5 \%$ level.

The variable SIZE is statistically significant at the 5\% level in all regressions, i.e. larger firms are more likely to refer to QCs when explaining their policy changes. ${ }^{42}$ Furthermore, untabulated results show that there are differences between 'large' and 'small' firms, using the median of SIZE from Panel A of Table 6 to split our sample firms: 'large' firms refer more frequently to relevance (18 vs 7), faithful representation (16 vs 8) and comparability (32 vs 13), in particular industry comparability (15 vs 1$)$, but there are only minor or no differences in references to understandability ( 5 vs 6 ) and transparency (9 vs 9). We find no statistical significance for the variables LEVERAGE $\mathrm{t}_{\mathrm{t}-1}$, PROFITABILITY $_{\mathrm{t}-1}$ and USLIST. Although firms from several industries refer less frequently to QCs than do firms from the reference

41 The following proxies for a country's legal enforcement are also not statistically significantly related to references to QCs: 'rule of law' from Kaufmann et al. (2009) and both the audit and enforcement proxies from Brown et al. (2014); we use the 2008 scores and the marginal effects ( $z$-statistics) are $-0.013(-0.46)$, $-0.002(-0.38)$ and $0.006(1.06)$, respectively.

42 Our sample comprises the largest firms in our ten countries, but there is substantial variation in firm size in our regression sample: the smallest and largest firms have a market capitalization of $\$ 0.7 \mathrm{bn}$ and $\$ 220 \mathrm{bn}$, respectively. Additionally, every country has at least one firm with a market capitalization below $\$ 4 \mathrm{bn}$ and at least one firm with a market capitalization above $\$ 37 \mathrm{bn}$. 
group (INDUSTRY2 - industrials), the entire set of industry variables is not statistically significant at the 5\% level (untabulated, based on a Wald test) in any of the regressions (the p-values for the three regressions are $0.056,0.106$ and 0.054 , respectively). ${ }^{43}$

These results are robust to the exclusion of reliability and relevance as reasons on the grounds that they are insufficient explanations (the results for MEASUREMENT and TRANSPARENCY are stronger: both are statistically significant at the $1 \%$ level); to the exclusion of policy changes with 'early adoption of standard' as the only reason on the grounds that such a change does not require an explanation in terms of QCs; and to the exclusion of policy changes for which there are only reasons in the 'other' category. They are also robust to including year fixed effects. When we estimate the second regression without the country and industry variables in order to reduce the number of independent variables, the results for the remaining variables are not materially affected, but the significance of MEASUREMENT reduces slightly ( $z$-statistic of $1.92 *$ compared to $2.09 * *$ in Table 6 ). When the 'immaterial' cases are not excluded (see the footnote to Table 2), our regression sample increases by five firm-year observations and the $z$-statistic of MEASUREMENT reduces slightly to $1.96 *$ compared to $2.09 * *$ in Table 6 . When we exclude changes regarding topic 12 , the $z$-statistic of MEASUREMENT increases to 3.62***. Finally, when we exclude financial firms from our regression, our sample size reduces to 256 firm-year observations and MEASUREMENT becomes statistically significant at the $1 \%$ level (marginal effect $=0.153$, $z$-statistic $=2.84 * * *)$

43 For a set of dummy variables where one dummy is selected as the reference group, the significance of any individual dummy depends on which dummy serves as the reference. Whether or not the entire set of dummy variables has an effect on the dependent variable has to be evaluated via a Wald test, which yields the same result regardless of which dummy serves as reference. 


\section{Conclusions}

Qualitative characteristics of financial information are discussed in the conceptual framework of the standard-setter, to whose work they are central. However, QCs are also important in the context of the choice and change of accounting policies by firms. The purpose of this paper is to investigate empirically the use of QCs by managers of firms, on which we believe that no evidence has previously been presented. The best setting for this is policy change in the context of reporting under IFRS, because IFRS allows more policy choice (and therefore more scope for change) than most other accounting systems (e.g. US GAAP), and it requires disclosure and explanation of policy changes that have a material effect.

We identify 434 policy changes from the financial statements of 514 large firms from 10 countries in the period 2006 to 2011 . Of these, 147 changes are explained, involving 204 reasons, of which 129 are references to QCs, mostly those found in the Framework of the IASB. The most frequently mentioned QC is comparability, particularly industry comparability. Given the importance of policy changes related to industry comparability and given the findings of Kvaal and Nobes (2012) about policy changes by French and Spanish firms away from their pre-IFRS practices, industry-related differences might become increasingly important compared to country-related differences. The IASB might consider whether comparability has been given a high enough ranking in its Framework, given that it could be considered central to investor decisions.

Other important QCs are relevance, faithful representation, understandability and transparency (not directly mentioned in the Framework). In our data, transparency is related to the visibility of financial information. For example, treating actuarial gains and losses as OCI shows the full surplus or deficit of a firm's pension plans on the balance sheet, which the 'corridor method' did not. Transparency can assist in understandability and could therefore be 
included in the definition of understandability in the Framework. Finally, another important reason for policy change was early adoption of amendments to accounting standards.

We find that QCs are referred to more often for measurement changes. This was our hypothesis, based on the notion that measurement changes are seen as more important. We also found greater reference to QCs by larger firms, perhaps because they are under closer scrutiny. Our results show no importance of the common/code legal dichotomy but a significant association between use of QCs and a measure of a country's transparency.

We enter some caveats. First, we examine policy changes because they provide a unique setting for the analysis of references to QCs, but such changes are infrequent. Nevertheless, most firms made at least one change in our period. A further caveat is that our data rely on managers' explanations being honest. It is possible that managers merely 'satisfice' by picking QCs at random in response to IAS 8's requirement for explanations, or that managers have hidden strategic objectives. However, the available reasons are all 'good' (e.g. faithful representation, comparability or early adoption), so it is not clear why managers would choose dishonestly among them. Furthermore, we found some evidence of trustworthiness in the reasons given, by assessing the references to industry comparability because these can be checked.

In conclusion, we have presented the first direct evidence about which QCs managers refer to when making accounting decisions and when they refer to QCs. For preparers, auditors and users, these findings enable comparisons across firms, including internationally. For auditors and regulators, our discovery that most policy changes are unexplained suggests some non-compliance with IFRS, especially as some changes which are mentioned by firms (implying a material effect) are not explained. The overall findings should be of importance to the IASB as it continues to revise its Framework, having opened the possibility of reconsidering the QCs (IASB 2013, paragraph 9.3 and Question 22, p. 193, and IASB 2014). 
In particular, we ask whether 'comparability' should be up-graded and whether 'transparency' should be included. We note that there is little evidence in our data that prudence is an important QC for managers when making accounting policy changes.

There are several possibilities for future research. Our preliminary investigation into the trustworthiness of the reasons given for policy change suggests the possibility of further work, perhaps involving interviews, on whether the stated reasons for policy changes and other policy decisions are misleading in any way. It would also be useful to investigate what 'transparency' is capturing that is not captured by the QCs that are in the Framework. Other avenues, beyond the scope of research on the conceptual framework, include asking whether policy changes are related to underlying economic events (e.g. poor results), whether the changes are discussed in press releases and analyst conference calls, and whether they matter to analysts or otherwise have economic consequences. 


\section{References}

AICPA, 1973. Objectives of financial statements. Report of the Study Group on the Objectives of Financial Statements. New York, NY: American Institute of Certified Public Accountants.

Allen, A. and Ramanna, K., 2013. Towards an understanding of the role of standard setters in standard setting. Journal of Accounting and Economics, 55 (1), 66-90.

André, P., Dionysiou, D. and Tsalavoutas, I., 2012. Mandatory adoption of IFRS by EU listed firms and comparability: determinants and analysts' forecasts. ESSEC and University of Stirling, Working Paper.

Ball, R., 2006. International Financial Reporting Standards (IFRS): pros and cons for investors. Accounting and Business Research, International Accounting Policy Forum, 36 (Supplement), 5-27.

Ball, R. and Brown, P., 1968. An empirical evaluation of accounting income numbers. Journal of Accounting Research, 6 (2), 159-178.

Ball, R., Kothari, S.P. and Robin, A., 2000. The effect of international institutional factors on properties of accounting earnings. Journal of Accounting and Economics, 29 (1), 1-51.

Bamber, L.S., Jiang, J., Petroni, K.R. and Wang, I.Y., 2010. Comprehensive income: who's afraid of performance reporting? Accounting Review, 85 (1), 97-126.

Barth, M.E., Beaver, W.H. and Landsman, W.R., 2001. The relevance of the value relevance literature for financial accounting standard setting: another view. Journal of Accounting and Economics, 31 (1-3), 77-104.

Barth, M.E., Konchitchki, Y. and Landsman, W.R., 2013. Cost of capital and earnings transparency. Journal of Accounting and Economics, 55 (2-3), 206-224.

Barth, M.E. and Schipper, K., 2008. Financial reporting transparency. Journal of Accounting, Auditing \& Finance, 23 (2), 173-190.

Baskerville, R.F., 2003. Hofstede never studied culture. Accounting, Organizations and Society, 28 (1), 1-14.

Basu, S., 1997. The conservatism principle and the asymmetric timeliness of earnings. Journal of Accounting and Economics, 24 (1), 3-37.

Braun, G.P. and Rodriguez, R.P., 2008. Earnings management and accounting values: a test of Gray (1988). Journal of International Accounting Research, 7 (2), 1-23.

Brown, P., Preiato, J. and Tarca, A., 2014. Measuring country differences in enforcement of accounting standards: an audit and enforcement proxy. Journal of Business Finance \& Accounting, 41 (1-2), 1-52.

Cairns, D., Massoudi, D., Taplin, R. and Tarca, A., 2011. IFRS fair value measurement and accounting policy choice in the United Kingdom and Australia. British Accounting Review, 43 (1), 1-21.

Canning, J.B., 1929. The economics of accountancy: a critical analysis of accounting theory. New York, NY: Ronald Press.

Christensen, H.B. and Nikolaev, V.V., 2013. Does fair value accounting for non-financial assets pass the market test? Review of Accounting Studies, 18 (3), 734-775. 
De Franco, G., Kothari, S.P. and Verdi, R.S., 2011. The benefits of financial statement comparability. Journal of Accounting Research, 49 (4), 895-931.

Dechow, P., Ge, W. and Schrand, C., 2010. Understanding earnings quality: a review of the proxies, their determinants and their consequences. Journal of Accounting and Economics, 50 (2-3), 344-401.

Dichev, I.D., Graham, J.R., Harvey, C.R. and Rajgopal, S., 2013. Earnings quality: evidence from the field. Journal of Accounting and Economics, 56 (2-3, Supplement), 1-33.

EFRAG, 2013a. Getting a better framework: reliability of financial information. Brussels: European Financial Reporting Advisory Group (and published by national standardsetters).

EFRAG, 2013b. Getting a better framework: prudence. Brussels: European Financial Reporting Advisory Group (and published by national standard-setters).

FASB, 2010. Statement of financial accounting concepts no. 8: conceptual framework for financial reporting. Norwalk, CT: Financial Accounting Standards Board.

Fields, T.D., Lys, T.Z. and Vincent, L., 2001. Empirical research on accounting choice. Journal of Accounting and Economics, 31 (1-3), 255-307.

Gore, P., 1992. The FASB conceptual framework project 1973-1985: an analysis. Manchester: Manchester University Press.

Gray, S.J., 1988. Towards a theory of cultural influence on the development of accounting systems internationally. Abacus, 24 (1), 1-15.

Hagerman, R.L. and Zmijewski, M.E., 1979. Some economic determinants of accounting policy choice. Journal of Accounting and Economics, 1 (2), 141-161.

Hail, L., 2013. Financial reporting and firm valuation: relevance lost or relevance regained? Accounting and Business Research, 43 (4), 329-358.

Haller, A. and Wehrfritz, M., 2013. The impact of national GAAP and accounting traditions on IFRS policy selection: evidence from Germany and the UK. Journal of International Accounting, Auditing and Taxation, 22 (1), 39-56.

Healy, P.M., 1985. The effect of bonus schemes on accounting decisions. Journal of Accounting and Economics, 7 (1-3), 85-107.

Hofstede, G., 1980. Culture's consequences: international differences in work-related values. Beverly Hills, CA: Sage.

Holthausen, R.W. and Leftwich, R.W., 1983. The economic consequences of accounting choice: implications of costly contracting and monitoring. Journal of Accounting and Economics, 5, 77-117.

Hunt, H.G., 1985. Potential determinants of corporate inventory accounting decisions. Journal of Accounting Research, 23 (2), 448-467.

Hunton, J.E., Libby, R. and Mazza, C.L., 2006. Financial reporting transparency and earnings management. Accounting Review, 81 (1), 135-157.

IASB, 2010. The conceptual framework for financial reporting. London: International Accounting Standards Board.

IASB, 2013. A review of the conceptual framework for financial reporting. London: International Accounting Standards Board. 
IASB, 2014. IASB update, May. London: International Accounting Standards Board.

IASC, 1989. Framework for the preparation and presentation of financial statements. London: International Accounting Standards Committee.

Jonas, G.J. and Blanchet, J., 2000. Assessing quality of financial reporting. Accounting Horizons, 14 (3), 353-363.

Jones, M. and Smith, M., 2014. Traditional and alternative methods of measuring the understandability of accounting narratives. Accounting, Auditing \& Accountability Journal, 27 (1), 183-208.

Joyce, E.J., Libby, R. and Sunder, S., 1982. Using the FASB's qualitative characteristics in accounting policy choices. Journal of Accounting Research, 20 (2), 654-675.

Kadous, K., Koonce, L. and Thayer, J.M., 2012. Do financial statement users judge relevance based on properties of reliability? Accounting Review, 87 (4), 1335-1356.

Kaufmann, D., Kraay, A. and Mastruzzi, M., 2009. Governance matters VIII: aggregate and individual governance indicators 1996-2008. World Bank Policy Research Working Paper No. 4978.

Koonce, L., Nelson, K.K. and Shakespeare, C.M., 2011. Judging the relevance of fair value for financial instruments. Accounting Review, 86 (6), 2075-2098.

Kvaal, E. and Nobes, C.W., 2010. International differences in IFRS policy choice: a research note. Accounting and Business Research, 40 (2), 173-187.

Kvaal, E. and Nobes, C.W., 2012. IFRS policy changes and the continuation of national patterns of IFRS practice. European Accounting Review, 21 (2), 343-371.

La Porta, R., Lopez-de-Silanes, F., Shleifer, A. and Vishny, R.W., 1998. Law and finance. Journal of Political Economy, 106 (6), 1113-1155.

LaFond, R. and Watts, R.L., 2008. The information role of conservatism. Accounting Review, 83 (2), 447-478.

Lindahl, F. and Schadéwitz, H., 2013. Are legal families related to financial reporting quality? Abacus, 49 (2), 242-267.

MacNeal, K., 1939. Truth in accounting. Philadelphia, PA: University of Pennsylvania Press.

Macve, R.H., 2014a. Fair value vs conservatism? Aspects of the history of accounting, auditing, business and finance from ancient Mesopotamia to modern China. British Accounting Review, forthcoming.

Macve, R.H., 2014b. What should be the nature and role of a revised Conceptual Framework for International Accounting Standards? China Journal of Accounting Studies, 2 (2), $77-95$.

Maines, L.A. and Wahlen, J.M., 2006. The nature of accounting information reliability: inferences from archival and experimental research. Accounting Horizons, 20 (4), 399425.

McSweeney, B., 2002. Hofstede's model of national cultural differences and their consequences: a triumph of faith - a failure of analysis. Human Relations, 55 (1), 89118.

Nobes, C.W., 1983. The evolution of the harmonising provisions of the 1980 and 1981 Companies Acts. Accounting and Business Research, 14 (53), 43-53. 
Nobes, C.W., 2009. The importance of being fair: an analysis of IFRS regulation and practice - a comment. Accounting and Business Research, 39 (4), 415-427.

Nobes, C.W. and Stadler, C., 2013. How arbitrary are international accounting classifications? Lessons from centuries of classifying in many disciplines, and experiments with IFRS data. Accounting, Organizations and Society, 38 (8), 573-595.

Paton, W.A., 1922. Accounting theory: with special reference to the corporate enterprise. New York, NY: Ronald Press.

Power, M., 2010. Fair value accounting, financial economics and the transformation of reliability. Accounting and Business Research, International Accounting Policy Forum, 40 (3), 197-210.

Rutherford, B.A., 2007. Financial reporting in the UK: a history of the Accounting Standards Committee, 1969-1990. London: Routledge.

Schattke, R.W., 1972. An analysis of Accounting Principles Board Statement No. 4. Accounting Review, 47 (2), 233-244.

Smith, M. and Taffler, R., 1992. Readability and understandability: different measures of the textual complexity of accounting narrative. Accounting, Auditing \& Accountability Journal, 5 (4), 84-98.

Sterling, R.R., 1967. A Statement of Basic Accounting Theory: a review article. Journal of Accounting Research, 5 (1), 95-112.

Sweeney, A.P., 1994. Debt-covenant violations and managers' accounting responses. Journal of Accounting and Economics, 17 (3), 281-308.

van Beest, F., Braam, G. and Boelens, S., 2009. Quality of financial reporting: measuring qualitative characteristics. Radboud University Nijmegen, Working Paper.

Watts, R.L. and Zimmerman, J.L., 1978. Towards a positive theory of the determination of accounting standards. Accounting Review, 53 (1), 112-134.

Watts, R.L. and Zimmerman, J.L., 1986. Positive accounting theory. Upper Saddle River, NJ: Prentice Hall.

Whittington, G., 2008. Fair value and the IASB/FASB conceptual framework project: an alternative view. Abacus, 44 (2), 139-168.

Zambon, S., 1996. Accounting and business economics traditions: a missing European connection? European Accounting Review, 5 (3), 401-411.

Zeff, S.A., 1999. The evolution of the conceptual framework for business enterprises in the United States. Accounting Historians Journal, 26 (2), 89-131.

Zeff, S.A., 2013. The objectives of financial reporting: a historical survey and analysis. Accounting and Business Research, 43 (4), 262-327. 


\section{Appendix 1. Outline of the meaning of the qualitative characteristics}

This Appendix draws on the 1989 Framework (IASC 1989), supplemented by the 2010 Framework (IASB 2010). The paragraph numbers refer to the 1989 Framework, unless otherwise stated. The QCs are shown in alphabetical order.

Accruals/matching: This appears in the Framework (para. 22) as part of the 'underlying assumption' of the accrual basis, by which the effect of a transaction is reported in the financial statements of the period to which it relates.

Comparability: This refers to both comparisons over time and comparisons between entities (paras. 39-42). It is therefore important that policies and policy changes are disclosed. Comparability is not the same as uniformity.

Faithful representation: In the 1989 Framework (para. 33), this is explained (circularly) in terms of representing faithfully what is purported to be represented. The 2010 Framework (para. QC12) suggests that this implies that information is complete, neutral and free from error.

Prudence/conservatism: This appears as 'prudence' in the Framework (para. 37), in which context it is 'the inclusion of a degree of caution in the exercise of the judgements needed in making the estimates required under conditions of uncertainty'.

Relevance: Relevance means (IASC 1989, para. 26/7; IASB 2010, para. QC6) that information is capable of being useful for the economic decisions of users, particularly equity and debt investors (existing and potential). The information could be predictive or confirmatory.

Reliability: In the 1989 Framework (para. 31), this included being free from error but was largely explained in terms of other concepts: faithful representation, substance over form, neutrality, prudence and completeness.

Timeliness: This is seen as a 'constraint' in the 1989 Framework (para. 43) but as an enhancing characteristic in the 2010 Framework (para. QC29). It means making information available in time for it to be relevant.

Transparency: This word is not defined in the Framework documents.

Understandability: The 2010 Framework (para. QC30) explains that this means clear and concise. The Framework (para. 25) assumes diligent users with reasonable business knowledge.

Verifiability: This is not a word found in the 1989 Framework, but the 2010 Framework (para. QC26) refers to it as being a clearer way of explaining part of the meaning of reliability. It means that different knowledgeable and independent observers could reach consensus. 


\section{Appendix 2. Data collection and coding procedures}

This Appendix provides details on how we collected the data on observable IFRS policy choices (see Table 1) and coded the explanations of policy changes (see Table 4).

IFRS policy choices: general procedures

Our default procedure is to record the IFRS policy choices based on the information provided in the financial statements or the accounting policies section of the notes. If there is no or insufficient information, other parts of the notes are searched for the relevant information. We ignore cases without a corresponding number in the current year; this applies when a firm states a policy choice which was previously made but is not applicable any more. We also ignore choices that relate only to an associate or joint venture.

\section{IFRS policy choices: specific procedures}

Topic 1 (income statement format): 'neither' is recorded if the income statement contains both a by-nature and a by-function expense or if the income statement contains so few lines that it is unclear whether it is 'by nature' or 'by function'. For financial firms, this topic is omitted because the distinction between 'by nature' and 'by function' is not applicable to most of them.

Topic 2 (operating profit shown or not): Many financial firms only have a line for earnings before taxation $(\mathrm{EBT})$ since EBT $=$ operating profit. Such cases are treated as inclusion of a line for operating profit.

Topic 3 (position of equity profits in the income statement): Many financial firms do not have a clear 'operating' or 'financing' section in the income statement; for these, we record that equity profits are shown immediately after 'operating' if they are clearly separately shown below the operating expenses items. We ignore cases where more than one options are used (which applies to 14 firm-year observations of 2 firms).

Topic 4 (balance sheet showing net assets or not): Showing 'net current assets' is treated as showing 'net assets'.

Topic 5 (liquidity order of the balance sheet): No specific procedures.

Topic 6 (OCI or statement of changes in equity): Only considered if part of the main financial statements.

Topic 7 (direct or indirect operating cash flow): Information is collected from the cash flow statement only. Otherwise most firms would use indirect cash flows because those using direct cash flows usually show a reconciliation of an income statement number to cash flow from operating activities in the notes.

Topic 8 (position of dividends received in the cash flow statement): We ignore cases where both options are used for different types of dividends (which applies to 49 firm-year observations of 12 firms).

Topic 9 (position of interest paid in the cash flow statement): Our assumption is that firms have interest paid, unless there is evidence against it. Therefore if a firm uses the indirect method and the cash flow statement does not show interest paid, it can be inferred that interest paid is included in operating cash flows. Interest paid includes capitalised borrowing costs. We ignore cases where both options are used (which applies to 52 firm-year observations of 12 firms). 
Topic 10 (some property at fair value or not): Only annual revaluations to fair value are considered, not initial recognition, impairments or first-time adoption of IFRS.

Topic 11 (investment property at fair value or not): The choice of valuing some investment property at fair value according to IAS $40.32 \mathrm{~A}$ is ignored if a firm generally uses the cost model.

Topic 12 (some designation of financial instruments at fair value or not): Some fair value designation is only recorded if a firm clearly states that financial instruments have been designated as 'at fair value through profit or loss', and the notes show a corresponding number to confirm this. The latter is necessary because many firms have boilerplate notes concerning fair value designation even though there is no such designation in the particular firm.

Topic 13 (interest on construction): No specific procedures.

Topic 14 (inventory costing): Any method other than FIFO or weighted average is ignored. This mainly applies to the 'retail method' used in the retail sector. For financial firms, this topic is omitted because most of them do not report inventories.

Topic 15 (treatment of actuarial gains/losses): Any choice that results in unrecognised actuarial gains and losses (AGL) is treated as using the corridor method, because the key difference between the corridor method and the other options is the existence of unrecognised AGL.

Topic 16 (treatment of joint ventures): The choice of designation as at fair value through profit or loss upon initial recognition (IAS 31.1) is ignored. This only applies to two financial firms in our sample (11 firm-year observations). We ignore the choice of one financial firm (3 firm-year observations) which claims to use both proportionate consolidation and the equity method.

Reasons for IFRS policy changes: procedures

Explanations for IFRS policy changes are generally from the notes to the financial statements (in particular from the accounting policies section), but occasionally from elsewhere in the annual report. The explanation may provide one or more reasons for the policy change. Several QCs (faithful representation, understandability and transparency) are not only scored if they are explicitly stated, but also if 'inferred'; the next paragraph provides further detail and the last section of this appendix provides examples.

Specific procedures: 'Relevance' is only scored if it is explicitly stated. 'Reliability' and 'relevance' are only scored for 'more reliable' and 'more relevant', i.e. not for 'reliable' and 'relevant' only. 'Comparability' includes 'alignment' and 'consistent'; it is not scored for comparability within a firm. 'Faithful representation (inferred)' includes any reference to better presentation of information. 'Understandability (inferred)' includes any reference to improved clarity of information. 'Transparency (inferred)' includes enhanced disclosure, additional information, and improved visibility.

\section{Reasons for IFRS policy changes: examples}

Reliability: 'The directors of the Company are of the view that the change in accounting method for interests in jointly controlled entities would provide more reliable, relevant and comparable information of its interests in jointly controlled entities on the Group's financial position, financial performance and cash flows, which is consistent with the basis adopted in the Group's PRC statutory financial statements prepared based on the 
CAS effective from 1 January 2007.' (Shenzhen Expressway, Annual Report 2007, p. 109) [We also score 'relevance' and 'comparability'.]

Relevance: 'The Group believes that subsequent measurement using the fair value model provides more relevant information about the financial performance of these assets.' (PICC Property and Casualty, Annual Report 2011, p. 68)

Faithful representation (inferred): 'Management believes that the change will more fairly present the fair value of assets and liabilities related to retiree benefits in the company's balance sheet and will eliminate significant volatility in its results of operations resulting from certain plans, the participants of which are all, or almost all, fully eligible to receive benefits.' (Alcatel-Lucent, Annual Report On Form 20-F 2007, p. 52) [We also score 'effect on financial statements'.]

Comparability: 'The presentation of the Consolidated Statement of Income has been changed to provide additional information in relation to costs and more alignment with industry practice.' (Royal Dutch Shell, Annual Report 2009, p. 101) [We also score 'transparency (inferred)' for the first reason.]

Verifiability: 'The change in presentation delivers more reliable and more relevant information as it facilitates comparison with other capital-market-oriented companies, increases the transparency and verifiability of the change in cash and cash equivalents and secures consistency in the indicators used by management to steer the group.' (Celesio, Annual Report 2009, p. 178) [We also score 'reliability', 'relevance', 'comparability', 'transparency' and 'economic/managerial environment'.]

Understandability: 'We believe this revised presentation will provide users of our financial statements with a better understanding of our business.' (Imperial Tobacco, Annual Report and Accounts 2007, p. 71)

Understandability (inferred): 'This change provides information that is clearer and more relevant.' (Unilever, Annual Report and Accounts 2011, p. 68) [We also score 'relevance'.]

Prudence/conservatism: 'Directors believe this provides a more conservative approach and better matches the short term future economic benefits of these borrowings, rather than expensing them over the life of the asset.' (Fortescue Metals Group, Annual Report 2008, p. 70) [We also score 'accruals/matching' for the second reason.]

Accruals/matching: 'Directors believe this provides a more conservative approach and better matches the short term future economic benefits of these borrowings, rather than expensing them over the life of the asset.' (Fortescue Metals Group, Annual Report 2008, p. 70) [We also score 'prudence/conservatism' for the first reason.]

Transparency: 'LANXESS decided to change the accounting treatment of provisions for pension and other post-employment benefit obligations in order to improve the transparency of financial reporting.' (LANXESS, Annual Report 2009, p. 122)

Transparency (inferred): 'The Group believes that recognising actuarial gains and losses in other comprehensive income results in better disclosures in the statement of financial position.' (Telkom, Annual Report 2010, p. 138)

Firm event: 'Carrying on with that method, especially after the recent acquisition of British companies with their sizable pension plans, would have made reported results more volatile due to the wide fluctuations in actuarial estimates.' (Autogrill, Report and 
Accounts 2008, p. 88) [We also score 'effect on financial statements' for the second part of the sentence.]

Effect on financial statements: 'This method appears more responding to the need to reflect in the financial statements the actual value of the liability compared to the corridor method, preserving at the same time the income statement from the recognition of the fluctuation of the actuarial components, highly volatile.' (Ansaldo STS, Consolidated Annual Report 2007, p. 118) [We also score 'faithful representation (inferred)' for the first part of the sentence.]

Economic/managerial environment: 'Presentation of the nature of expenses reflects more appropriately the manner in which the diversified Group manages its expenses.' (Wesfarmers, Annual Report 2007, p. 59)

Due to another policy change: 'Following its adoption of the option allowed under IAS 19 to recognise actuarial gains and losses directly in equity, the Bouygues group has for the first time presented a comparative statement of recognised income and expense.' (Bouygues, Registration Document 2007, p. 171)

Early adoption of standard: 'In 2008 the FCC Group presented a consolidated statement of recognised income and expense for the first time as a result of the early application of the amendments to IAS 1.' (FCC, Annual Report 2008, p. 103)

Anticipated change to standard: 'The Group believes that equity accounting aligns it with the expected changes that will be introduced with IFRS 11 Joint Arrangements.' (Telkom, Integrated Annual Report 2011, p. 148)

Requirements of local regulator: 'In 2008 the Bank of Spain amended the formats of the standard public financial statements and brought them into line with the general international consensus, thereby completing the process towards ensuring the comparability of the financial statements between credit institutions.' (Banco Popular, Annual Report 2008, p. 201) 


\section{Appendix 3. Definitions of variables}

Data sources, including Worldscope codes, are shown in square brackets.

Dependent variable:

$\mathrm{QC}$

Dummy for a QC as a reason for an IFRS policy change, 0 otherwise; QCs comprise those from the Framework plus transparency [hand-collected]

Independent variables:

MEASUREMENT Dummy for a change of a measurement choice, i.e. topics 10 to 16 (see Table 1), 0 otherwise [hand-collected]

NOT2OPTIONS Dummy for a change which is not to or from using two options on a topic (i.e. the choice ' $a+b$ ' on topics 6 or 14, see Table 1), 0 otherwise [hand-collected]

COMMONLAW Dummy for common law, i.e. ' 1 ' for common law and ' 0 ' for code law [La Porta et al. 1998; additionally, China is classified as code law]

TRANSPARENCY Transparency measure of a firm's country: 'secrecy vs transparency' scores of Braun and Rodriguez (2008) multiplied by -1 , so that a higher value implies more transparency; the scores operationalise Gray's (1988) framework and are based on Hofstede's (1980) data [Braun and Rodriguez 2008, Table 2]

SIZE Natural logarithm of market capitalization (in US dollars) [WC07210]

LEVERAGE Leverage $=$ total liabilities / total assets, industry-mean adjusted: leverage of a firm minus the mean leverage of all other firms in the same year and 'supersector' (i.e. the first two digits of the ICB code are the same) [WC03351/WC02999, WC07040]

PROFITABILITY Profitability = return on assets, industry-mean adjusted: profitability of a firm minus the mean profitability of all other firms in the same year and 'supersector' (i.e. the first two digits of the ICB code are the same); winsorized at the $1^{\text {st }}$ and $99^{\text {th }}$ percentiles [WC08326/100, WC07040]

USLIST Dummy for US listing (20-F filed with the SEC), 0 otherwise [hand-collected: EDGAR database]

Topic fixed effects:

Dummy for a policy change for the respective topic:

TOPIC1 (income statement format), TOPIC2 (operating profit shown or not), TOPIC3 (position of equity profits), TOPIC4 (showing net assets or not), TOPIC5 (liquidity order), TOPIC6 (OCI or statement of changes in equity), TOPIC7 (direct or indirect cash flow), TOPIC8 (position of dividends received), TOPIC9 (position of interest paid), TOPIC10 (some property at fair value or not), TOPIC11 (investment property at fair value or not), TOPIC12 (some fair value designation or not), TOPIC13 (interest on construction), TOPIC14 (inventory costing), TOPIC15 (treatment of actuarial gains/losses), TOPIC16 (treatment of joint ventures ) 
Country fixed effects:

Dummy for the respective country (abbreviations are according to the ISO 3166-1 alpha-2 code):

AU (Australia), CH (Switzerland), CN (China), DE (Germany), ES (Spain), FR

(France), GB (United Kingdom), HK (Hong Kong), IT (Italy), ZA (South Africa)

Industry fixed effects:

Dummy for the respective industry according to the first digit of the Industry

Classification Benchmark (ICB) [WC07040]:

INDUSTRY0 (oil and gas), INDUSTRY1 (basic materials), INDUSTRY2 (industrials), INDUSTRY3 (consumer goods), INDUSTRY4 (health care), INDUSTRY5 (consumer services), INDUSTRY6 (telecommunications), INDUSTRY7 (utilities), INDUSTRY8 (financials), INDUSTRY9 (technology) 
Figure 1. Qualitative characteristics of the IASC's Framework.

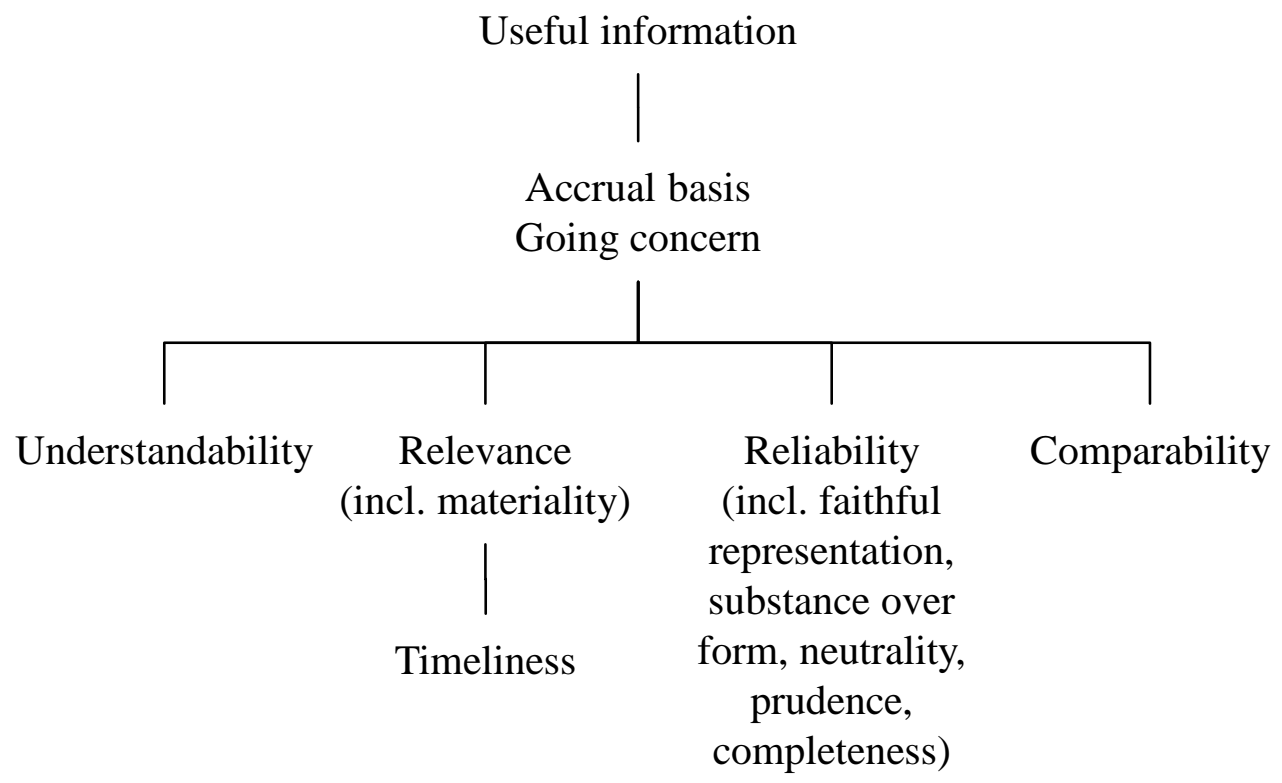

This figure shows the qualitative characteristics of the Framework of the International Accounting Standards Committee (IASC 1989). The terms are explained in Appendix 1. 
Table 1. IFRS policy topics.

\begin{tabular}{|c|c|c|}
\hline Topic & IFRS policy options & Standard $^{b}$ \\
\hline $1^{\mathrm{a}}$ & $\begin{array}{l}\text { (a) income statement by function } \\
\text { (b) by nature } \\
\text { (c) neither }\end{array}$ & IAS 1.99 \\
\hline 2 & $\begin{array}{l}\text { (a) inclusion of a line for EBIT or operating profit } \\
\text { (b) no line included }\end{array}$ & IAS 1.82 \\
\hline 3 & $\begin{array}{l}\text { (a) equity accounting results included in 'operating' } \\
\text { (b) immediately after } \\
\text { (c) after 'finance' }\end{array}$ & IAS $1.82^{c}$ \\
\hline 4 & $\begin{array}{l}\text { (a) balance sheet showing net assets } \\
\text { (b) showing assets = credits }\end{array}$ & IAS $1.54^{\mathrm{c}}$ \\
\hline 5 & $\begin{array}{l}\text { (a) balance sheet with liquidity decreasing (cash at top) } \\
\text { (b) liquidity increasing }\end{array}$ & IAS $1.54^{\mathrm{c}}$ \\
\hline 6 & $\begin{array}{l}\text { (a) OCI, excluding shareholder transactions } \\
\text { (b) statement of changes in equity } \\
\text { (a+b) both }\end{array}$ & IAS $1.10^{\mathrm{d}}$ \\
\hline 7 & $\begin{array}{l}\text { (a) indirect operating cash flows } \\
\text { (b) direct }\end{array}$ & IAS 7.18 \\
\hline 8 & $\begin{array}{l}\text { (a) dividends received shown as operating cash flow } \\
\text { (b) not }\end{array}$ & IAS 7.31 \\
\hline 9 & $\begin{array}{l}\text { (a) interest paid shown as operating cash flow } \\
\text { (b) not }\end{array}$ & IAS 7.31 \\
\hline 10 & $\begin{array}{l}\text { (a) some property at fair value } \\
\text { (b) only cost }\end{array}$ & IAS 16.29 \\
\hline 11 & $\begin{array}{l}\text { (a) investment property at fair value } \\
\text { (b) at cost }\end{array}$ & IAS 40.30 \\
\hline 12 & $\begin{array}{l}\text { (a) some designation of financial instruments at fair value } \\
\text { (b) none }\end{array}$ & IAS 39.9 \\
\hline 13 & $\begin{array}{l}\text { (a) capitalization of interest on construction } \\
\text { (b) expensing }\end{array}$ & IAS $23.7 / 10^{\mathrm{d}}$ \\
\hline $14^{\mathrm{a}}$ & $\begin{array}{l}\text { (a) First in, first out (FIFO) for inventory cost } \\
\text { (b) weighted average } \\
\text { (a+b) both }\end{array}$ & IAS 2.25 \\
\hline 15 & $\begin{array}{l}\text { (a) actuarial gains and losses to OCI } \\
\text { (b) corridor method } \\
\text { (c) to income in full }\end{array}$ & IAS $19.92 / 3$ \\
\hline 16 & $\begin{array}{l}\text { (a) proportionate consolidation of joint ventures } \\
\text { (b) equity method }\end{array}$ & IAS 31.30 \\
\hline
\end{tabular}

This table shows 16 IFRS policy topics on which choices were observable during 2005 to 2011 . Topics 1 to 9 are presentation issues and topics 10 to 16 are measurement issues. The topics are as in Kvaal and Nobes (2010).

${ }^{\mathrm{a}}=$ not appropriate, and therefore not collected, for financial firms.

${ }^{\mathrm{b}}=$ versions of the standards ruling from 2005 to 2011 (to 2008 for topics 6 and 13).

${ }^{\mathrm{c}}=$ IAS 1 specifies lists of items to be shown in financial statements, but does not specify their order.

${ }^{\mathrm{d}}=$ removed for accounting periods beginning on 1 January 2009. 
Table 2. Sample of firms and data on IFRS policy changes.

\begin{tabular}{|c|c|c|c|c|c|c|c|c|c|c|c|}
\hline Country & $\mathbf{A U}$ & $\mathbf{C H}$ & $\mathbf{C N}$ & $\mathbf{D E}$ & ES & FR & GB & HK & IT & $\mathbf{Z A}$ & $\sum$ \\
\hline Index constituents on $31 / 12 / 2005$ & 50 & 26 & 40 & 40 & 35 & 40 & 100 & 33 & 40 & 40 & \\
\hline Index constituents on $31 / 12 / 2010$ & 50 & 20 & 40 & 40 & 35 & 40 & 100 & 45 & 40 & 40 & \\
\hline Unique firms per country & 64 & 29 & 58 & 49 & 45 & 47 & 131 & 51 & 52 & 52 & 578 \\
\hline Excluded: foreign firms & 5 & - & - & 1 & 2 & 5 & 2 & 13 & 2 & 9 & 39 \\
\hline US GAAP used in every year & - & 8 & - & 1 & - & - & 1 & - & - & - & 10 \\
\hline Firms with less than two years of data & 1 & 1 & 1 & - & 2 & - & 6 & - & 2 & 2 & 15 \\
\hline Firms & 58 & 20 & 57 & 47 & 41 & 42 & 122 & 38 & 48 & 41 & 514 \\
\hline IFRS policy changes (2006-2011) & 37 & 21 & 50 & 44 & 47 & 56 & 73 & 30 & 33 & 43 & 434 \\
\hline IFRS policy choices (2006-2011) & 3,361 & 1,490 & 3,873 & 3,443 & 2,908 & 3,207 & 7,561 & 2,789 & 3,283 & 2,811 & 34,726 \\
\hline Proportion of choices changed & $1.1 \%$ & $1.4 \%$ & $1.3 \%$ & $1.3 \%$ & $1.6 \%$ & $1.7 \%$ & $1.0 \%$ & $1.1 \%$ & $1.0 \%$ & $1.5 \%$ & $1.2 \%$ \\
\hline Firms with one or more policy change & 25 & 11 & 35 & 24 & 29 & 30 & 46 & 17 & 19 & 25 & 261 \\
\hline Firms with one or more explanation & 10 & 6 & 17 & 11 & 17 & 11 & 19 & 3 & 12 & 16 & 122 \\
\hline \multicolumn{12}{|l|}{ IFRS policy changes } \\
\hline - with an explanation & 12 & 9 & 20 & 13 & 18 & 14 & 25 & 5 & 13 & 18 & 147 \\
\hline - without an explanation & 25 & 12 & 30 & 31 & 29 & 42 & 48 & 25 & 20 & 25 & 287 \\
\hline thereof: change mentioned & 4 & 3 & 3 & 9 & 6 & 15 & 6 & 4 & 2 & 1 & 53 \\
\hline - proportion of changes explained & $32 \%$ & $43 \%$ & $40 \%$ & $30 \%$ & $38 \%$ & $25 \%$ & $34 \%$ & $17 \%$ & $39 \%$ & $42 \%$ & $34 \%$ \\
\hline Reas & 16 & 9 & 29 & 22 & 20 & 25 & 36 & 7 & 19 & 21 & 204 \\
\hline Reasons excluding reliability and relevance & 13 & 7 & 22 & 19 & 19 & 22 & 32 & 5 & 19 & 18 & 176 \\
\hline Firm-years & 33 & 17 & 43 & 34 & 37 & 41 & 59 & 23 & 29 & 38 & 354 \\
\hline Excluded & 1 & 1 & 1 & 1 & 1 & 4 & 3 & 2 & 1 & 4 & 19 \\
\hline No data in Worldscope & - & - & - & 3 & 2 & - & 4 & - & 1 & 2 & 12 \\
\hline Regression sample & 32 & 16 & 42 & 30 & 34 & 37 & 52 & 21 & 27 & 32 & 323 \\
\hline
\end{tabular}

This table shows the sample of firms and data on IFRS policy changes per country. The countries are Australia (AU), Switzerland (CH), China (CN), Germany (DE), Spain (ES), France (FR), United Kingdom (GB), Hong Kong (HK), Italy (IT) and South Africa (ZA). The sample firms comprise the constituents of the major stock market index of the respective country on 31 December 2005 or 31 December 2010 or both: S\&P/ASX-50 (AU), SMI (CH), Hang Seng China Enterprises Index (CN), DAX-30 \& 10 largest (by market capitalization) constituents of MDAX-50 (DE), IBEX-35 (ES), CAC-40 (FR), FTSE-100 (GB), Hang Seng (HK), (S\&P/MIB40) FTSE/MIB-40 (IT) and FTSE/JSE Top 40 (ZA). Excluded are foreign firms (e.g. Telecom New Zealand in $\mathrm{AU})$; regarding firms with a dual-listed structure which are index constituents in two countries, BHP Billiton is excluded from GB (because its group headquarters are in Melbourne), Brambles is excluded from GB (because it unified its dual listed structure in 2006 and became an Australian company) and Rio Tinto is excluded from AU (because its headquarters are in London). Firms with less than two years of data are excluded because two years of data are necessary in order to identify policy changes. Excluded from the regression sample are firm-years in which a firm mentions a change but provides no reason because the effect was said to be immaterial and those in which a firm does not provide an explanation because the item is new or the previous choice is no longer applicable (which mainly applies to topic 12). Data on index constituents are from the respective stock exchanges or index providers, and the remaining data are hand-collected. 
Table 3. Number of IFRS policy changes per country.

\begin{tabular}{|c|c|c|c|c|c|c|c|c|c|c|c|c|}
\hline Topic & IFRS policy topic & $\mathbf{A U}$ & $\mathrm{CH}$ & $\mathbf{C N}$ & DE & ES & FR & GB & HK & IT & $\mathbf{Z A}$ & $\sum$ \\
\hline 1 & $\begin{array}{l}\text { Income statement format } \\
\text { - from (a) to (b) / (b) to (a) } \\
\text { - from (a) to (c) / (c) to (a) } \\
\text { - from (b) to (c) / (c) to (b) }\end{array}$ & $\begin{array}{c}3 \\
1 / 0 \\
0 / 1 \\
1 / 0\end{array}$ & $\begin{array}{c}0 \\
0 / 0 \\
0 / 0 \\
0 / 0\end{array}$ & $\begin{array}{c}1 \\
0 / 1 \\
0 / 0 \\
0 / 0\end{array}$ & $\begin{array}{c}1 \\
0 / 1 \\
0 / 0 \\
0 / 0\end{array}$ & $\begin{array}{c}0 \\
0 / 0 \\
0 / 0 \\
0 / 0\end{array}$ & $\begin{array}{c}1 \\
0 / 0 \\
0 / 0 \\
1 / 0\end{array}$ & $\begin{array}{c}9 \\
2 / 2 \\
4 / 1 \\
0 / 0\end{array}$ & $\begin{array}{c}1 \\
0 / 1 \\
0 / 0 \\
0 / 0\end{array}$ & $\begin{array}{c}1 \\
0 / 1 \\
0 / 0 \\
0 / 0\end{array}$ & $\begin{array}{c}2 \\
0 / 0 \\
0 / 1 \\
0 / 1\end{array}$ & $\begin{array}{l}19(9) \\
3 / 6 \\
4 / 3 \\
2 / 1\end{array}$ \\
\hline 2 & $\begin{array}{l}\text { Operating profit shown or not } \\
\text { - from (a) to (b) / (b) to (a) }\end{array}$ & $\begin{array}{c}6 \\
1 / 5\end{array}$ & $\begin{array}{c}1 \\
0 / 1\end{array}$ & $\begin{array}{c}2 \\
2 / 0\end{array}$ & $\begin{array}{c}3 \\
2 / 1\end{array}$ & $\begin{array}{c}1 \\
0 / 1\end{array}$ & $\begin{array}{c}0 \\
0 / 0\end{array}$ & $\begin{array}{c}3 \\
2 / 1\end{array}$ & $\begin{array}{c}2 \\
2 / 0\end{array}$ & $\begin{array}{c}0 \\
0 / 0\end{array}$ & $\begin{array}{c}4 \\
0 / 4\end{array}$ & $\begin{array}{c}22(1) \\
9 / 13\end{array}$ \\
\hline 3 & $\begin{array}{l}\text { Position of equity profits } \\
\text { - from (a) to (b) / (b) to (a) } \\
\text { - from (a) to (c) / (c) to (a) } \\
\text { - from (b) to (c) / (c) to (b) }\end{array}$ & $\begin{array}{c}4 \\
0 / 0 \\
1 / 0 \\
2 / 1\end{array}$ & $\begin{array}{c}0 \\
0 / 0 \\
0 / 0 \\
0 / 0\end{array}$ & $\begin{array}{c}4 \\
0 / 0 \\
0 / 0 \\
3 / 1\end{array}$ & $\begin{array}{c}2 \\
0 / 0 \\
0 / 0 \\
1 / 1\end{array}$ & $\begin{array}{c}1 \\
0 / 0 \\
0 / 0 \\
0 / 1\end{array}$ & $\begin{array}{l}1 \\
0 / 0 \\
0 / 1 \\
0 / 0\end{array}$ & $\begin{array}{c}6 \\
2 / 1 \\
1 / 0 \\
1 / 1\end{array}$ & $\begin{array}{c}0 \\
0 / 0 \\
0 / 0 \\
0 / 0\end{array}$ & $\begin{array}{c}1 \\
0 / 0 \\
0 / 0 \\
0 / 1\end{array}$ & $\begin{array}{c}0 \\
0 / 0 \\
0 / 0 \\
0 / 0\end{array}$ & $\begin{array}{l}19(6) \\
2 / 1 \\
2 / 1 \\
7 / 6\end{array}$ \\
\hline 4 & $\begin{array}{l}\text { Showing net assets or not } \\
\text { - from (a) to (b) / (b) to (a) }\end{array}$ & $\begin{array}{c}0 \\
0 / 0\end{array}$ & $\begin{array}{c}0 \\
0 / 0\end{array}$ & $\begin{array}{c}2 \\
0 / 2\end{array}$ & $\begin{array}{c}0 \\
0 / 0\end{array}$ & $\begin{array}{c}0 \\
0 / 0\end{array}$ & $\begin{array}{c}0 \\
0 / 0\end{array}$ & $\begin{array}{c}3 \\
2 / 1\end{array}$ & $\begin{array}{c}3 \\
3 / 0\end{array}$ & $\begin{array}{c}0 \\
0 / 0\end{array}$ & $\begin{array}{c}0 \\
0 / 0\end{array}$ & $\begin{array}{l}8(3) \\
5 / 3\end{array}$ \\
\hline 5 & $\begin{array}{l}\text { Liquidity order } \\
\text { - from (a) to (b) / (b) to (a) }\end{array}$ & $\begin{array}{c}0 \\
0 / 0\end{array}$ & $\begin{array}{c}0 \\
0 / 0\end{array}$ & $\begin{array}{c}0 \\
0 / 0\end{array}$ & $\begin{array}{c}1 \\
0 / 1\end{array}$ & $\begin{array}{c}1 \\
0 / 1\end{array}$ & $\begin{array}{c}0 \\
0 / 0\end{array}$ & $\begin{array}{c}2 \\
0 / 2\end{array}$ & $\begin{array}{c}1 \\
0 / 1\end{array}$ & $\begin{array}{c}0 \\
0 / 0\end{array}$ & $\begin{array}{c}1 \\
0 / 1\end{array}$ & $\begin{array}{l}6(5) \\
0 / 6\end{array}$ \\
\hline 6 & $\begin{array}{l}\text { OCI or statement of changes in equity } \\
\text { - from }(a) \text { to }(b) /(b) \text { to }(a) \\
\text { - from (a) to }(a+b) /(a+b) \text { to }(a) \\
\text { - from (b) to }(a+b) /(a+b) \text { to }(b)\end{array}$ & $\begin{array}{c}3 \\
0 / 2 \\
1 / 0 \\
0 / 0\end{array}$ & $\begin{array}{c}6 \\
0 / 1 \\
0 / 1 \\
4 / 0\end{array}$ & $\begin{array}{l}1 \\
0 / 1 \\
0 / 0 \\
0 / 0\end{array}$ & $\begin{array}{l}13 \\
0 / 3 \\
1 / 4 \\
5 / 0\end{array}$ & $\begin{array}{l}20 \\
0 / 8 \\
7 / 0 \\
5 / 0\end{array}$ & $\begin{array}{c}19 \\
0 / 2 \\
0 / 3 \\
14 / 0\end{array}$ & $\begin{array}{c}9 \\
0 / 6 \\
0 / 3 \\
0 / 0\end{array}$ & $\begin{array}{c}6 \\
0 / 4 \\
0 / 1 \\
1 / 0\end{array}$ & $\begin{array}{c}6 \\
0 / 3 \\
0 / 1 \\
2 / 0\end{array}$ & $\begin{array}{l}12 \\
0 / 2 \\
4 / 0 \\
6 / 0\end{array}$ & $\begin{array}{c}95(31) \\
0 / 32 \\
13 / 13 \\
37 / 0\end{array}$ \\
\hline 7 & $\begin{array}{l}\text { Direct or indirect cash flow } \\
\text { - from (a) to (b) / (b) to (a) }\end{array}$ & $\begin{array}{c}3 \\
0 / 3\end{array}$ & $\begin{array}{c}2 \\
1 / 1\end{array}$ & $\begin{array}{c}0 \\
0 / 0\end{array}$ & $\begin{array}{c}0 \\
0 / 0\end{array}$ & $\begin{array}{c}1 \\
0 / 1\end{array}$ & $\begin{array}{c}0 \\
0 / 0\end{array}$ & $\begin{array}{c}1 \\
1 / 0\end{array}$ & $\begin{array}{c}0 \\
0 / 0\end{array}$ & $\begin{array}{c}0 \\
0 / 0\end{array}$ & $\begin{array}{c}3 \\
2 / 1\end{array}$ & $\begin{array}{c}10(4) \\
4 / 6\end{array}$ \\
\hline 8 & $\begin{array}{l}\text { Position of dividends received } \\
\text { - from (a) to (b) / (b) to (a) }\end{array}$ & $\begin{array}{c}0 \\
0 / 0\end{array}$ & $\begin{array}{c}2 \\
1 / 1\end{array}$ & $\begin{array}{c}2 \\
2 / 0\end{array}$ & $\begin{array}{c}1 \\
1 / 0\end{array}$ & $\begin{array}{c}2 \\
0 / 2\end{array}$ & $\begin{array}{c}2 \\
1 / 1\end{array}$ & $\begin{array}{c}0 \\
0 / 0\end{array}$ & $\begin{array}{c}2 \\
1 / 1\end{array}$ & $\begin{array}{c}0 \\
0 / 0\end{array}$ & $\begin{array}{c}0 \\
0 / 0\end{array}$ & $\begin{array}{c}11(3) \\
6 / 5\end{array}$ \\
\hline 9 & $\begin{array}{l}\text { Position of interest paid } \\
\text { - from (a) to (b) / (b) to (a) }\end{array}$ & $\begin{array}{c}1 \\
1 / 0\end{array}$ & $\begin{array}{c}1 \\
1 / 0\end{array}$ & $\begin{array}{c}12 \\
12 / 0\end{array}$ & $\begin{array}{c}3 \\
3 / 0\end{array}$ & $\begin{array}{c}2 \\
1 / 1\end{array}$ & $\begin{array}{c}1 \\
1 / 0\end{array}$ & $\begin{array}{c}8 \\
3 / 5\end{array}$ & $\begin{array}{c}3 \\
2 / 1\end{array}$ & $\begin{array}{c}5 \\
5 / 0\end{array}$ & $\begin{array}{c}1 \\
1 / 0\end{array}$ & $\begin{array}{c}37(11) \\
30 / 7\end{array}$ \\
\hline 10 & $\begin{array}{l}\text { Some property at fair value or not } \\
\text { - from (a) to (b) / (b) to (a) }\end{array}$ & $\begin{array}{c}1 \\
1 / 0\end{array}$ & $\begin{array}{c}0 \\
0 / 0\end{array}$ & $\begin{array}{c}1 \\
1 / 0\end{array}$ & $\begin{array}{c}0 \\
0 / 0\end{array}$ & $\begin{array}{c}0 \\
0 / 0\end{array}$ & $\begin{array}{c}0 \\
0 / 0\end{array}$ & $\begin{array}{c}0 \\
0 / 0\end{array}$ & $\begin{array}{c}0 \\
0 / 0\end{array}$ & $\begin{array}{c}0 \\
0 / 0\end{array}$ & $\begin{array}{c}0 \\
0 / 0\end{array}$ & $\begin{array}{c}2(1) \\
2 / 0\end{array}$ \\
\hline 11 & $\begin{array}{l}\text { Investment property at fair value or not } \\
\text { - from (a) to (b) / (b) to (a) }\end{array}$ & $\begin{array}{c}0 \\
0 / 0\end{array}$ & $\begin{array}{c}0 \\
0 / 0\end{array}$ & $\begin{array}{c}1 \\
0 / 1\end{array}$ & $\begin{array}{c}0 \\
0 / 0\end{array}$ & $\begin{array}{c}1 \\
0 / 1\end{array}$ & $\begin{array}{c}0 \\
0 / 0\end{array}$ & $\begin{array}{c}1 \\
0 / 1\end{array}$ & $\begin{array}{c}0 \\
0 / 0\end{array}$ & $\begin{array}{c}0 \\
0 / 0\end{array}$ & $\begin{array}{c}0 \\
0 / 0\end{array}$ & $\begin{array}{c}3(3) \\
0 / 3\end{array}$ \\
\hline 12 & $\begin{array}{l}\text { Some fair value designation or not } \\
\text { - from (a) to (b) / (b) to (a) }\end{array}$ & $\begin{array}{c}7 \\
2 / 5\end{array}$ & $\begin{array}{c}2 \\
2 / 0\end{array}$ & $\begin{array}{c}3 \\
0 / 3\end{array}$ & $\begin{array}{c}5 \\
1 / 4\end{array}$ & $\begin{array}{c}0 \\
0 / 0\end{array}$ & $\begin{array}{c}6 \\
1 / 5\end{array}$ & $\begin{array}{c}12 \\
7 / 5\end{array}$ & $\begin{array}{c}3 \\
1 / 2\end{array}$ & $\begin{array}{c}7 \\
3 / 4\end{array}$ & $\begin{array}{c}9 \\
1 / 8\end{array}$ & $\begin{array}{l}54(3) \\
18 / 36\end{array}$ \\
\hline 13 & $\begin{array}{l}\text { Interest on construction } \\
\text { - from (a) to (b) / (b) to (a) }\end{array}$ & $\begin{array}{c}1 \\
1 / 0\end{array}$ & $\begin{array}{c}1 \\
0 / 1\end{array}$ & $\begin{array}{c}2 \\
0 / 2\end{array}$ & $\begin{array}{c}2 \\
0 / 2\end{array}$ & $\begin{array}{c}1 \\
0 / 1\end{array}$ & $\begin{array}{c}1 \\
0 / 1\end{array}$ & $\begin{array}{c}5 \\
0 / 5\end{array}$ & $\begin{array}{c}1 \\
0 / 1\end{array}$ & $\begin{array}{c}0 \\
0 / 0\end{array}$ & $\begin{array}{c}1 \\
1 / 0\end{array}$ & $\begin{array}{l}15(8) \\
2 / 13\end{array}$ \\
\hline 14 & $\begin{array}{l}\text { Inventory costing } \\
\text { - from (a) to }(b) /(b) \text { to }(a) \\
\text { - from (a) to }(a+b) /(a+b) \text { to }(a) \\
\text { - from (b) to }(a+b) /(a+b) \text { to }(b)\end{array}$ & $\begin{array}{c}3 \\
1 / 0 \\
2 / 0 \\
0 / 0\end{array}$ & $\begin{array}{c}0 \\
0 / 0 \\
0 / 0 \\
0 / 0\end{array}$ & $\begin{array}{c}4 \\
2 / 0 \\
1 / 0 \\
0 / 1\end{array}$ & $\begin{array}{c}2 \\
0 / 0 \\
0 / 0 \\
1 / 1\end{array}$ & $\begin{array}{c}2 \\
0 / 0 \\
0 / 0 \\
0 / 2\end{array}$ & $\begin{array}{l}2 \\
0 / 0 \\
0 / 0 \\
1 / 1\end{array}$ & $\begin{array}{c}8 \\
1 / 0 \\
2 / 1 \\
3 / 1\end{array}$ & $\begin{array}{c}4 \\
2 / 2 \\
0 / 0 \\
0 / 0\end{array}$ & $\begin{array}{c}3 \\
1 / 0 \\
1 / 1 \\
0 / 0\end{array}$ & $\begin{array}{c}4 \\
1 / 0 \\
1 / 0 \\
1 / 1\end{array}$ & $\begin{array}{l}32(3) \\
8 / 2 \\
7 / 2 \\
6 / 7\end{array}$ \\
\hline 15 & $\begin{array}{l}\text { Treatment of actuarial gains/losses } \\
\text { - from (a) to (b) / (b) to (a) } \\
\text { - from (a) to (c) / (c) to (a) } \\
\text { - from (b) to (c) / (c) to (b) }\end{array}$ & $\begin{array}{c}4 \\
0 / 1 \\
0 / 3 \\
0 / 0\end{array}$ & $\begin{array}{c}5 \\
0 / 5 \\
0 / 0 \\
0 / 0\end{array}$ & $\begin{array}{c}3 \\
0 / 1 \\
1 / 1 \\
0 / 0\end{array}$ & $\begin{array}{c}9 \\
0 / 9 \\
0 / 0 \\
0 / 0\end{array}$ & $\begin{array}{c}9 \\
0 / 4 \\
0 / 5 \\
0 / 0\end{array}$ & $\begin{array}{c}17 \\
0 / 16 \\
0 / 1 \\
0 / 0\end{array}$ & $\begin{array}{c}3 \\
1 / 2 \\
0 / 0 \\
0 / 0\end{array}$ & $\begin{array}{c}3 \\
0 / 2 \\
0 / 1 \\
0 / 0\end{array}$ & $\begin{array}{c}8 \\
1 / 4 \\
0 / 1 \\
1 / 1\end{array}$ & $\begin{array}{c}3 \\
0 / 2 \\
0 / 1 \\
0 / 0\end{array}$ & $\begin{array}{c}64(33) \\
2 / 46 \\
1 / 13 \\
1 / 1\end{array}$ \\
\hline 16 & $\begin{array}{l}\text { Treatment of joint ventures } \\
\text { - from (a) to (b) / (b) to (a) }\end{array}$ & $\begin{array}{c}1 \\
0 / 1\end{array}$ & $\begin{array}{c}1 \\
1 / 0\end{array}$ & $\begin{array}{c}12 \\
12 / 0\end{array}$ & $\begin{array}{c}2 \\
2 / 0\end{array}$ & $\begin{array}{c}6 \\
4 / 2\end{array}$ & $\begin{array}{c}6 \\
5 / 1\end{array}$ & $\begin{array}{c}3 \\
0 / 3\end{array}$ & $\begin{array}{c}1 \\
0 / 1\end{array}$ & $\begin{array}{c}2 \\
2 / 0\end{array}$ & $\begin{array}{c}3 \\
3 / 0\end{array}$ & $\begin{array}{c}37(23) \\
29 / 8\end{array}$ \\
\hline
\end{tabular}

This table shows the number of IFRS policy changes in the period 2006 to 2011 per country for each topic. The topics are as in Table 1 and the countries are as in Table 2. See Appendix 2 for details on the topics. The number 
in brackets in the column ' $\Sigma$ ' shows the number of changes with an explanation. Data on IFRS policy changes are hand-collected. 
Table 4. Frequencies of reasons for IFRS policy changes.

\begin{tabular}{|c|c|c|c|c|}
\hline & Total & $\begin{array}{c}\text { One reason } \\
\text { only }\end{array}$ & $\begin{array}{l}\text { More than one } \\
\text { reason }\end{array}$ & $\begin{array}{c}\text { Measurement } \\
\text { topics only }\end{array}$ \\
\hline \multicolumn{5}{|c|}{ Qualitative characteristics - Framework } \\
\hline - Reliability & 3 & 0 & 3 & $2(67 \%)$ \\
\hline - Relevance & 25 & 7 & 18 & $14(56 \%)$ \\
\hline - Faithful representation & 24 & 12 & 12 & $20(83 \% *)$ \\
\hline thereof: inferred & 24 & 12 & 12 & $20(83 \% *)$ \\
\hline - Comparability & 45 & 21 & 24 & $29(64 \%)$ \\
\hline - Verifiability & 1 & 0 & 1 & $0(0 \%)$ \\
\hline - Timeliness & - & - & - & $-(-)$ \\
\hline - Understandability & 11 & 5 & 6 & $5(45 \%)$ \\
\hline thereof: inferred & 7 & 2 & 5 & $4(57 \%)$ \\
\hline - Prudence/conservatism & 1 & 0 & 1 & $1(100 \%)$ \\
\hline - Accruals/matching & 1 & 0 & 1 & $1(100 \%)$ \\
\hline \multicolumn{5}{|l|}{ Qualitative characteristic - other } \\
\hline - Transparency & 18 & 9 & 9 & $12(67 \%)$ \\
\hline thereof: inferred & 8 & 3 & 5 & $4(50 \%)$ \\
\hline \multicolumn{5}{|l|}{ Economic } \\
\hline - Firm event & 14 & 8 & 6 & $10(71 \%)$ \\
\hline - Effect on financial statements & 6 & 2 & 4 & $6(100 \% *)$ \\
\hline - Economic/managerial environment & 11 & 3 & 8 & $2(18 \% *)$ \\
\hline \multicolumn{5}{|l|}{ Other } \\
\hline - Due to another policy change & 8 & 8 & 0 & $0(0 \% *)$ \\
\hline - Early adoption of standard & 24 & 23 & 1 & $8(33 \% *)$ \\
\hline - Anticipated change to standard & 4 & 1 & 3 & $4(100 \%)$ \\
\hline - Requirements of local regulator & 8 & 7 & 1 & $1(13 \% *)$ \\
\hline Total reasons & 204 & 106 & 98 & $115(56 \%)$ \\
\hline
\end{tabular}

Comparability breakdown

- Comparability industry

- Comparability international

- Comparability over time

- Comparability parent

- Comparability subsidiary

- Comparability local GAAP

- Comparability other

$\begin{array}{cccc}16 & 5 & 11 & 7(44 \%) \\ 3 & 1 & 2 & 2(67 \%) \\ 1 & 0 & 1 & 1(100 \%) \\ 3 & 1 & 2 & 3(100 \%) \\ 1 & 1 & 0 & 1(100 \%) \\ 14 & 10 & 4 & 11(79 \%) \\ 7 & 3 & 4 & 4(57 \%)\end{array}$

This table reports the frequencies of reasons provided for IFRS policy changes in the period 2006 to 2011. Each reason receives a score of 1 . See Appendix 2 for the coding procedure. The columns 'One reason only' and 'More than one reason' distinguish whether one reason or more than one reason is provided in an explanation of policy change. In the column 'Measurement topics only' (topics 10 to 16), * denotes that the proportion is significantly different from $56 \%$ (the proportion of reasons on measurement topics) at the $5 \%$ level based on a test of proportions (two-sided); significant results show the reasons for which measurement topics are over- or under-represented. Data on IFRS policy changes are hand-collected. 
Table 5. Univariate analysis of reasons for IFRS policy changes.

N $\quad \%$ A $\quad \%$ B $\quad$ p-value

\section{Considering all reasons:}

- QCs (A) vs economic and other (B)

$204 \quad 63 \% \quad 37 \% \quad 0.00 *$

- QCs excluding transparency (A) vs economic and other (B)

- QCs excluding reliability and relevance (A) vs economic and other (B)

Considering only reasons referring to QCs:

- Comparability (A) vs relevance (B)

- Measurement (A) vs presentation (B) change

$65 \% \quad 35 \% \quad 0.00 *$

This table reports results of univariate analyses of the reasons for IFRS policy changes in the period 2006 to 2011 from Table 4. 'QCs' denotes qualitative characteristics. 'A' and 'B' denote different groups that are compared. ' $\mathrm{N}$ ' is the number of reasons considered for each line of analysis. ' $\% \mathrm{~A}$ ' and ' $\% \mathrm{~B}$ ' are the proportions of reasons that correspond to these groups. 'p-value' reports the p-value for a two-sample test of proportions; * indicates that the proportion of the two groups is significantly different at the $5 \%$ level (two-sided). Data on IFRS policy changes are hand-collected. 
Table 6. Circumstances under which managers explain IFRS policy changes by referring to qualitative characteristics.

Panel A: Summary statistics of regression variables.

\begin{tabular}{lrrrrrrrr}
\hline Variable & N & Mean & StdDev & Min & Q1 & Median & Q3 & Max \\
\hline & & & & & & & & \\
QC & 323 & 0.257 & 0.438 & & & & & \\
MEASUREMENT & 323 & 0.539 & 0.499 & & & & & \\
NOT2OPTIONS & 323 & 0.833 & 0.374 & & & & & \\
COMMONLAW & 323 & 0.424 & 0.495 & & & & & \\
TRANSPARENCY & 323 & -43.189 & 11.666 & -60 & -53 & -40 & -31 & -26 \\
SIZE & 323 & 16.132 & 1.206 & 13.507 & 15.214 & 15.989 & 16.930 & 19.209 \\
LEVERAGE $_{\mathrm{t}-1}$ & 323 & 0.012 & 0.171 & -0.574 & -0.088 & 0.020 & 0.112 & 0.545 \\
PROFITABILITY $_{\mathrm{t}-1}$ & 323 & -0.007 & 0.070 & -0.178 & -0.048 & -0.013 & 0.013 & 0.301 \\
USLIST & 323 & 0.146 & 0.353 & & & & &
\end{tabular}

Panel B: Regression analysis.

\begin{tabular}{|c|c|c|c|c|c|c|}
\hline & $\begin{array}{c}\text { Marginal } \\
\text { effect }\end{array}$ & $z$-stat & $\begin{array}{c}\text { Marginal } \\
\text { effect }\end{array}$ & $z$-stat & $\begin{array}{c}\text { Marginal } \\
\text { effect }\end{array}$ & $z$-stat \\
\hline Dependent variable & $\mathrm{QC}$ & & QC & & $\mathrm{QC}$ & \\
\hline TOPIC1 & 0.524 & $(2.96) * * *$ & & & 0.499 & $(2.86) * * *$ \\
\hline TOPIC2 & -0.029 & $(-0.31)$ & & & -0.065 & $(-0.92)$ \\
\hline TOPIC3 & 0.259 & $(1.39)$ & & & 0.262 & $(1.47)$ \\
\hline TOPIC4 & 0.312 & $(1.16)$ & & & 0.330 & $(1.38)$ \\
\hline TOPIC5 & 0.853 & $(17.56)^{* * *}$ & & & 0.841 & $(16.68)^{* * *}$ \\
\hline TOPIC6 & -0.154 & $(-4.26) * * *$ & & & -0.167 & $(-4.61) * * *$ \\
\hline TOPIC7 & 0.552 & $(2.19) * *$ & & & 0.557 & $(2.45)^{* *}$ \\
\hline TOPIC8 & 0.282 & $(1.36)$ & & & 0.307 & $(1.59)$ \\
\hline TOPIC9 & 0.212 & $(1.35)$ & & & 0.275 & $(1.62)$ \\
\hline TOPIC10 & 0.698 & $(3.35) * * *$ & & & 0.702 & $(3.23) * * *$ \\
\hline TOPIC11 & 0.686 & $(2.76) * * *$ & & & 0.726 & $(3.05) * * *$ \\
\hline TOPIC12 & -0.042 & $(-0.55)$ & & & -0.047 & $(-0.60)$ \\
\hline TOPIC13 & 0.083 & $(0.60)$ & & & 0.084 & $(0.63)$ \\
\hline TOPIC14 & 0.095 & $(0.81)$ & & & 0.092 & $(0.78)$ \\
\hline TOPIC15 & 0.686 & $(5.74) * * *$ & & & 0.681 & $(6.06) * * *$ \\
\hline TOPIC16 & 0.762 & $(7.60) * * *$ & & & 0.779 & $(8.41) * * *$ \\
\hline MEASUREMENT & & & 0.098 & $(2.09) * *$ & & \\
\hline NOT2OPTIONS & & & 0.248 & $(7.22) * * *$ & & \\
\hline $\mathrm{AU}$ & -0.055 & $(-0.99)$ & -0.087 & $(-1.46)$ & & \\
\hline $\mathrm{CH}$ & 0.044 & $(0.36)$ & 0.102 & $(0.85)$ & & \\
\hline $\mathrm{CN}$ & -0.036 & $(-0.61)$ & 0.024 & $(0.31)$ & & \\
\hline $\mathrm{DE}$ & -0.044 & $(-0.71)$ & -0.029 & $(-0.37)$ & & \\
\hline ES & -0.107 & $(-3.10) * * *$ & -0.119 & $(-2.41)^{* * *}$ & & \\
\hline FR & -0.109 & $(-3.17) * * *$ & -0.086 & $(-1.40)$ & & \\
\hline HK & -0.113 & $(-3.75) * * *$ & -0.139 & $(-2.58) * * *$ & & \\
\hline IT & -0.026 & $(-0.39)$ & -0.044 & $(-0.60)$ & & \\
\hline $\mathrm{ZA}$ & -0.031 & $(-0.42)$ & -0.064 & $(-0.91)$ & & \\
\hline TRANSPARENCY & & & & & 0.005 & $(2.21)^{* *}$ \\
\hline INDUSTRY0 & -0.100 & $(-3.44) * * *$ & -0.104 & $(-1.70)^{*}$ & -0.111 & $(-3.79) * * *$ \\
\hline INDUSTRY1 & -0.060 & $(-1.24)$ & -0.040 & $(-0.64)$ & -0.045 & $(-0.75)$ \\
\hline INDUSTRY3 & -0.050 & $(-1.16)$ & -0.038 & $(-0.58)$ & -0.051 & $(-1.10)$ \\
\hline INDUSTRY4 & -0.123 & $(-5.24) * * *$ & -0.173 & $(-5.35) * * *$ & -0.126 & $(-5.24) * * *$ \\
\hline
\end{tabular}




\begin{tabular}{|c|c|c|c|c|c|c|}
\hline INDUSTRY5 & -0.106 & $(-3.60) * * *$ & -0.085 & $(-1.40)$ & -0.115 & $(-3.66) * * *$ \\
\hline INDUSTRY6 & -0.060 & $(-1.54)$ & -0.034 & $(-0.39)$ & -0.052 & $(-1.14)$ \\
\hline INDUSTRY7 & -0.051 & $(-1.02)$ & -0.071 & $(-1.02)$ & -0.048 & $(-0.85)$ \\
\hline INDUSTRY8 & -0.113 & $(-2.92) * * *$ & -0.101 & $(-1.92)^{*}$ & -0.114 & $(-2.82)^{* * *}$ \\
\hline INDUSTRY9 & -0.079 & $(-1.69)^{*}$ & -0.123 & $(-1.83) *$ & -0.106 & $(-3.04) * * *$ \\
\hline SIZE & 0.059 & $(2.97) * * *$ & 0.052 & $(2.49)^{* *}$ & 0.058 & $(2.98)^{* * *}$ \\
\hline LEVERAGE $_{\mathrm{t}-1}$ & 0.113 & $(1.00)$ & 0.143 & $(0.98)$ & 0.109 & $(0.97)$ \\
\hline PROFITABILITY $_{\mathrm{t}-1}$ & -0.412 & $(-1.31)$ & -0.163 & $(-0.48)$ & -0.455 & $(-1.54)$ \\
\hline USLIST & 0.003 & $(0.05)$ & 0.027 & $(0.38)$ & 0.008 & $(0.12)$ \\
\hline $\mathrm{p}$-value & 0.000 & & 0.005 & & 0.000 & \\
\hline Pseudo $\mathrm{R}^{2}$ & 0.420 & & 0.173 & & 0.401 & \\
\hline$\%$ classified correctly & 84.83 & & 75.23 & & 84.21 & \\
\hline Observations (firms) & $323(248)$ & & $323(248)$ & & $323(248)$ & \\
\hline
\end{tabular}

This table reports regression results of an analysis of the circumstances under which managers explain IFRS policy changes by referring to QCs in the period 2006 to 2011. Panel A shows summary statistics of the regression variables: mean (percentage for dummy variables), standard deviation (StdDev), minimum (Min), first quartile (Q1), median, third quartile (Q3) and maximum (Max). N is the number of firm-year observations. The variables are QC (dummy for a QC as a reason for a change), MEASUREMENT (dummy for a change of a measurement choice), NOT2OPTIONS (dummy for a change which is not to or from using two options), COMMONLAW (dummy for common law), TRANSPARENCY (transparency measure of a firm's country), SIZE (natural logarithm of market capitalization in US dollars), LEVERAGE (industry-adjusted leverage), PROFITABILITY (industry-adjusted return on assets) and USLIST (dummy for US listing). See Appendix 3 for more details on the definitions of the variables. Panel B reports the regression results. The logistic regressions are of the general form $\mathrm{QC}_{\mathrm{it}}=\alpha+$ topic $_{\text {it }} \beta+$ country $_{\text {it }} \gamma+$ industry $_{\mathrm{it}} \delta+\theta \mathrm{SIZE}_{\mathrm{it}}+\lambda \mathrm{LEVERAGE}_{\mathrm{i}, \mathrm{t}-1}+\mu$ PROFITABILITY $_{\mathrm{i}, \mathrm{t}-1}+\sigma$ USLIST $_{\mathrm{it}}+\varepsilon_{\mathrm{it}}$; topic, country and industry denote vectors of variables. The results are marginal effects at means and the corresponding $z$-statistics (for dummy variables, the marginal effect is for a discrete change of the dummy variable from 0 to 1 ). The reference groups of the country and industry fixed effects are GB (United Kingdom) and INDUSTRY2 (industrials), respectively. There is no reference group for the topic fixed effects due to firm-year observations with more than one policy change and therefore more than one topic dummy with a value of ' 1 '. See Table 4 and Appendix 1 for details of the QCs. See Table 2 for details of the regression sample. The results are based on standard errors clustered by firm. *, ** and *** indicates significance at the $10 \%, 5 \%$ and $1 \%$ level, respectively (two-sided). Data on IFRS policy changes are handcollected, data on US listing are from the EDGAR database and the remaining data are from Worldscope. 